\section{Journal of Home \\ Economics}

http://homeEcon.menofia.edu.eg

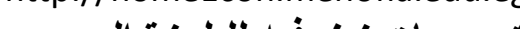

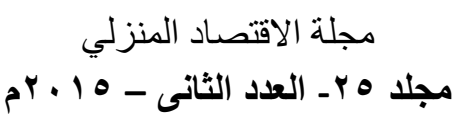

ISSN 1110-2578

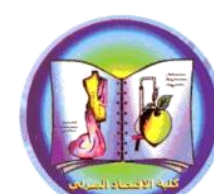

رؤيه تشكيليه للملامس المرئية للأقمشة لعمل تصن

سناء محمد عبد الوهاب شاهين، رحاب عادل شاكر الفيشاوى المادي

قسم الملابس و النسيج - كلية الاقتصاد المنزلي - جامعة المنوفية فئية

ملخص البحث: - م:

يُهدف البحث الى إيجاد فكرا" ابداعيا متأثرا بالملامس المرئية للأقمشة المختلفة

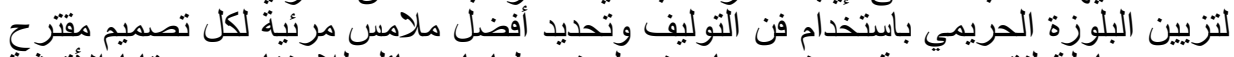

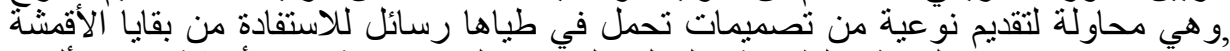

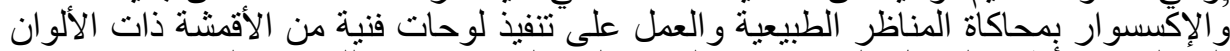

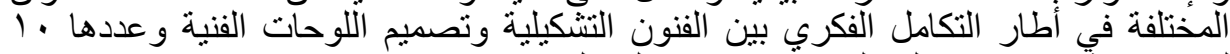

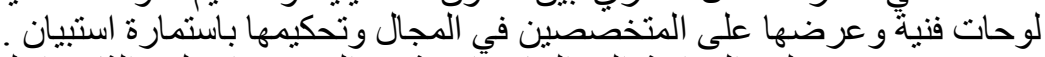

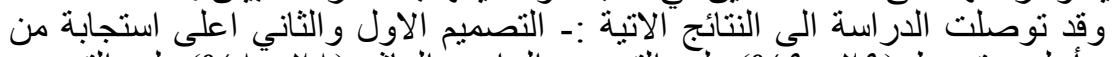

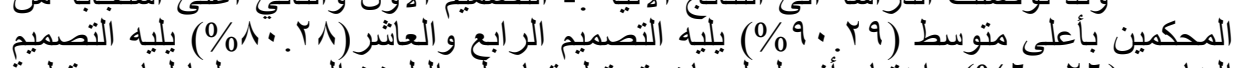

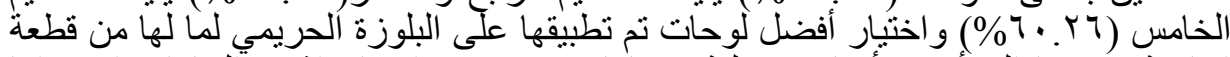

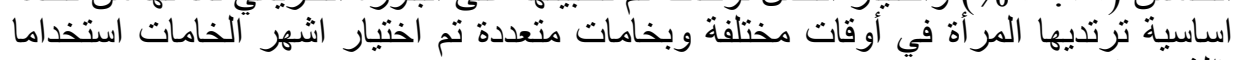
(الثيفون).

\title{
المقدمه والمشكله البحثيه :
}

تعتبر الفنون التشكيلية أساس التشكيل بمجموعة من الخامات المتاحة أمام الفنان بحيث الفيثة

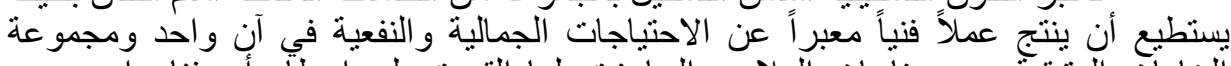

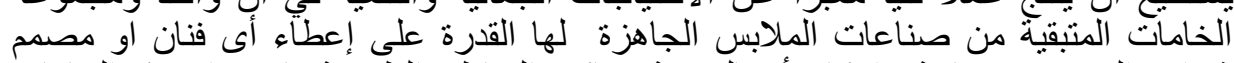

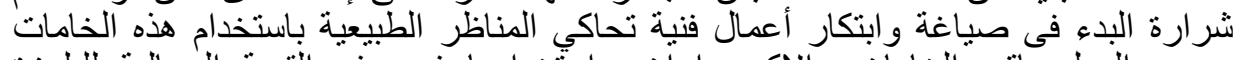

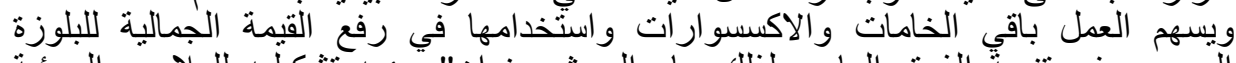

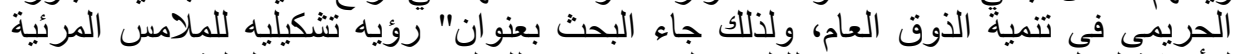

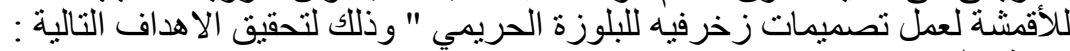
الهداف البحث: البمث:

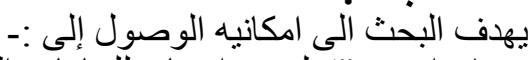

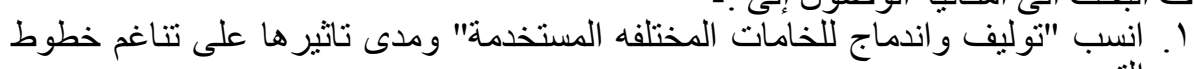

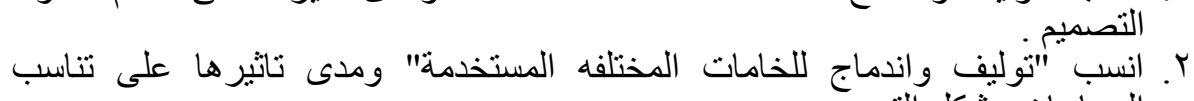

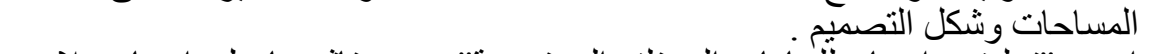

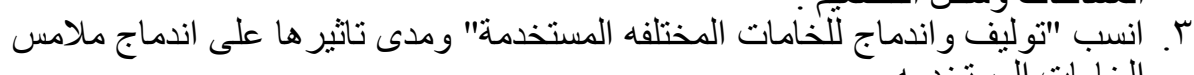
ع. انسب "توليف واندمأج للخامات المختانلفه المستخدمة" ومدى تانثير ها على ملانئمه التاثير

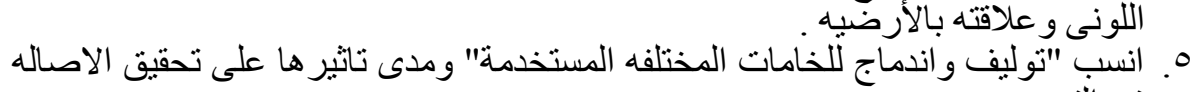
فى التصميم . 


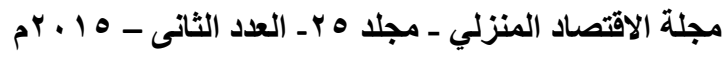

T. . انسب "توليف و اندماج للخامات المختلفه المستخدمة" ومدى تاثير ها على تحقيق الحداثه

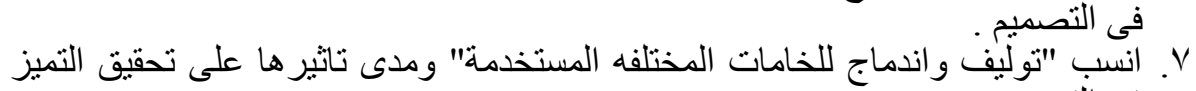

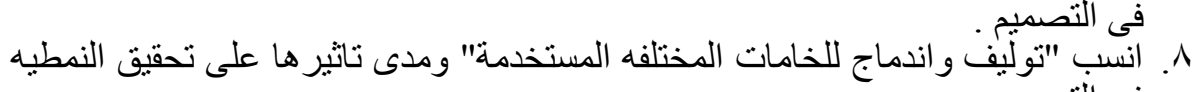

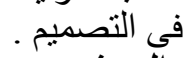

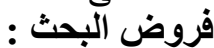

ا ـ توجد فروق دالبحث داله احصائيه يبين اندماج الخامات ومدى تاثير ها على تتاغم خطوط

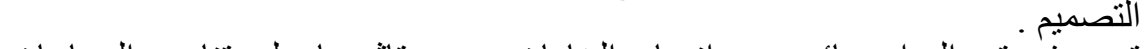
r- توجد فروق داله الهدائيه يبين اندماج الخامات ومدى تاثير ها على تتاسب المساحات

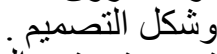

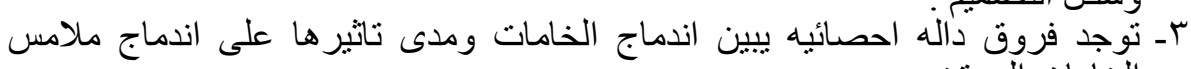

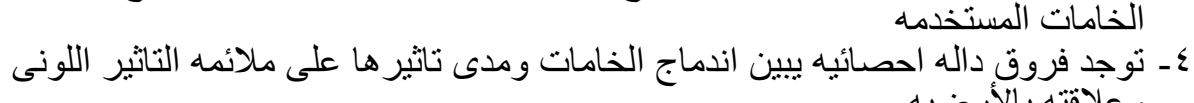

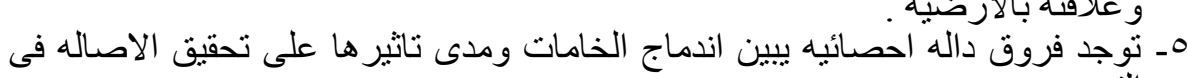

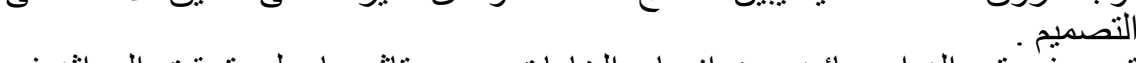
7- توجد فربوف داله احصائيه يبين اندماج الخامات ومدى تاثيرها على تحقيق الحداثه فى

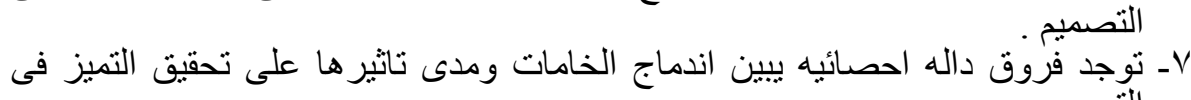

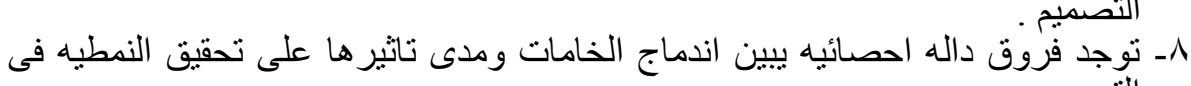
منهج البحث: التصميم . يعتمد البحث على المنهج التحليلي والمنهج التجريبي فيما يتم تطبيقه واستعر اضه لنو عبة التصميمات المقترحة و المنفذة.

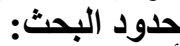
أولا :- الإطار النظري وقد تم التعرض فيه لبعض الدراسات السابقة المرتبطة بموضوع البحثي.

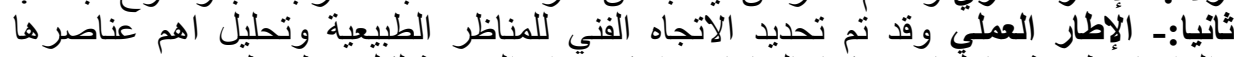

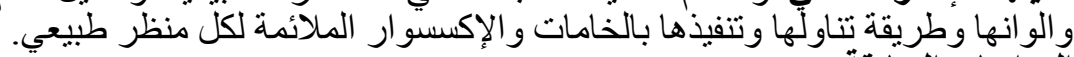

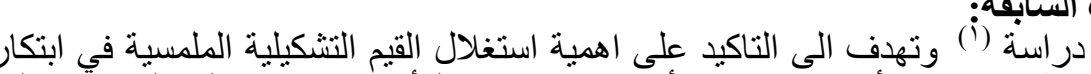

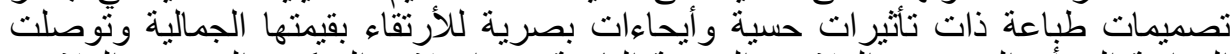

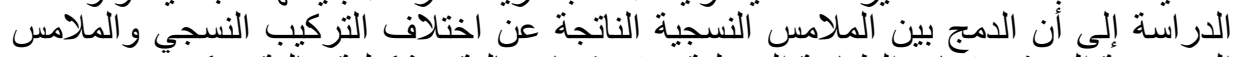

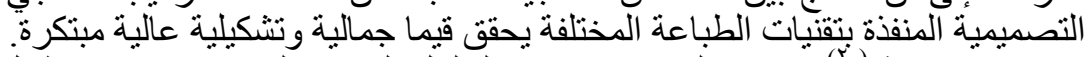

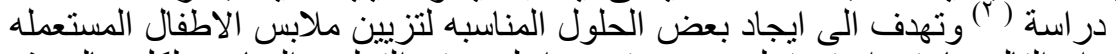

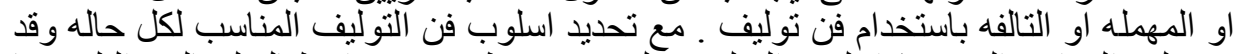

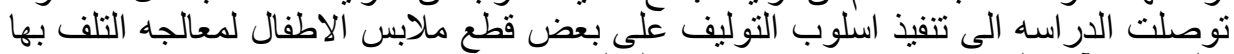

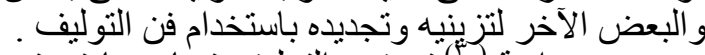

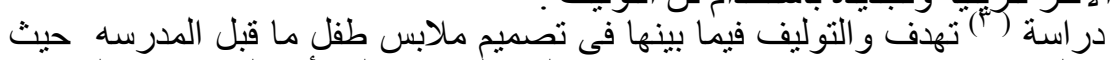

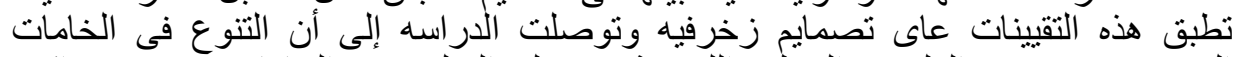

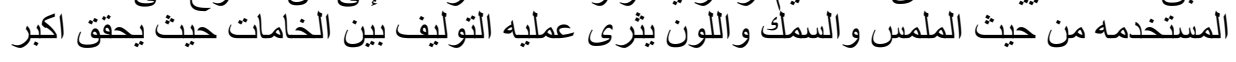




\section{مجلة الاقتصاد المنزلي - مجلد ه بـ العدد الثانى ـ 1 ـ بrم}

قدر من التو افق الجمالى ، كما ان التقينيات النسجيه تتيح فرصه الحصول على تاثير ات متنو عه

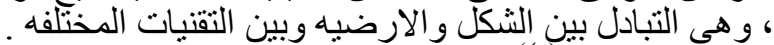

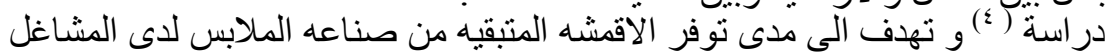

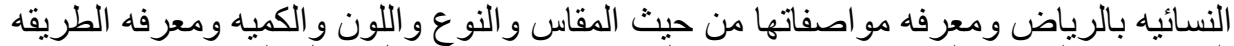

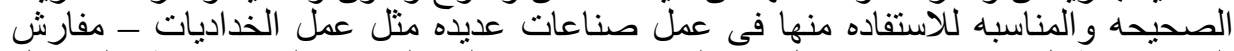

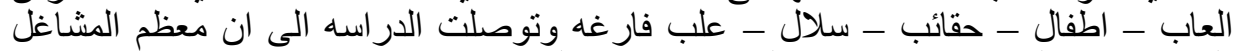

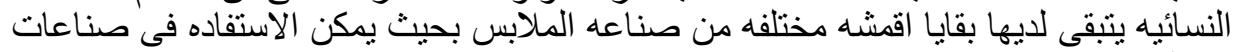

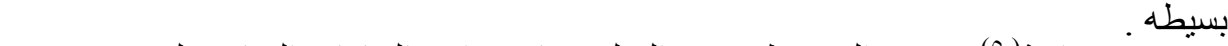

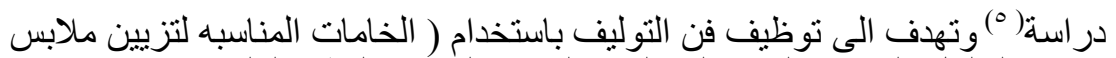

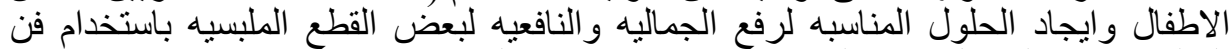

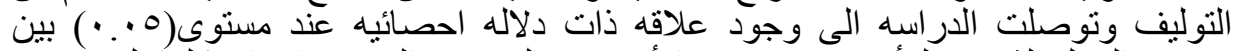

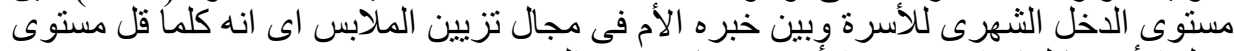

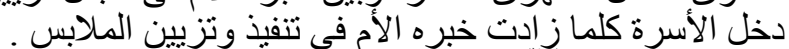

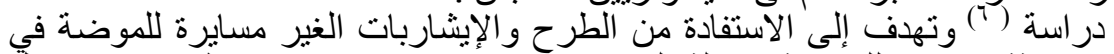

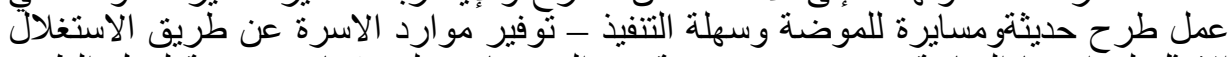

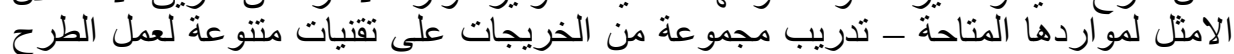

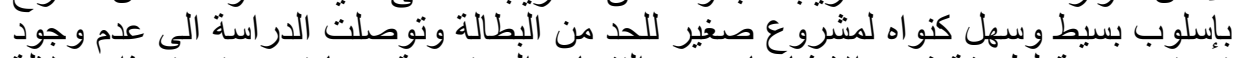

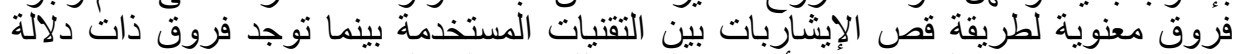

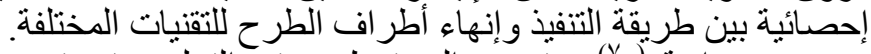

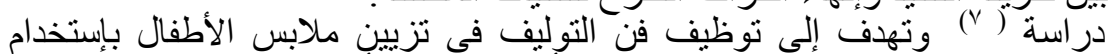

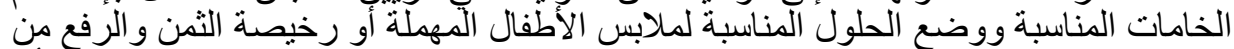

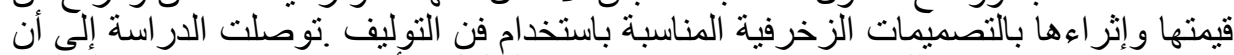

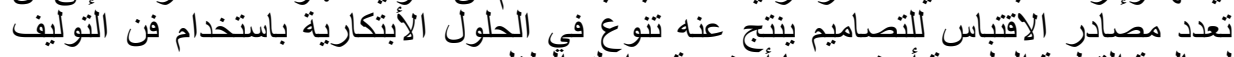

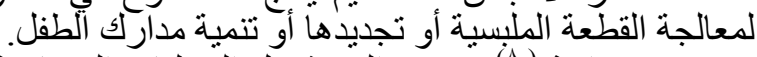

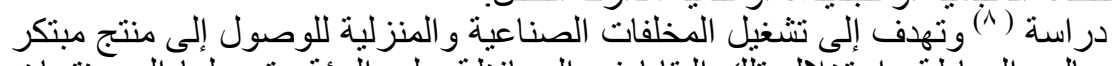

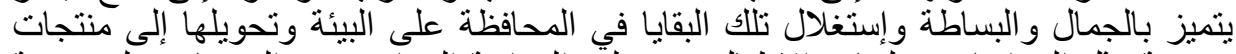

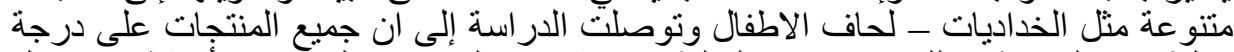

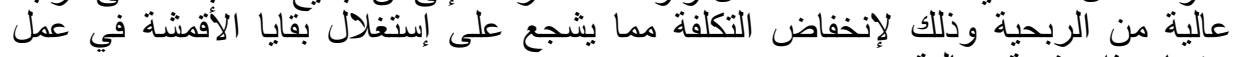

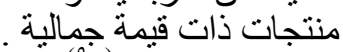

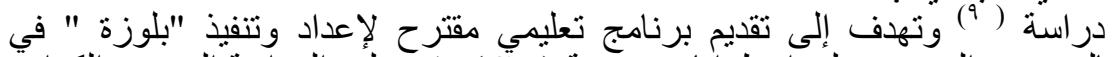

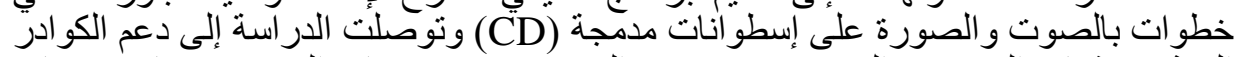

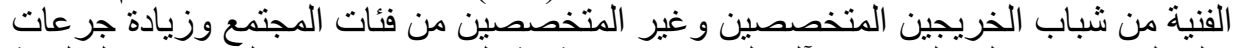

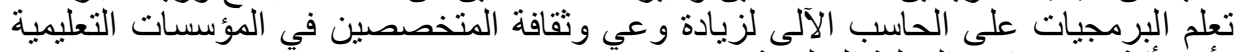
لأنهم أكثر تناحما مع العملية التعليمية. دراسة (") ويهذف البحثث إلى تحقيق القيمة الملمسية في التصميمات الزخرفية

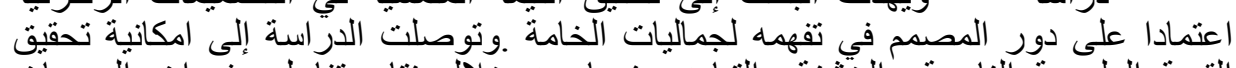

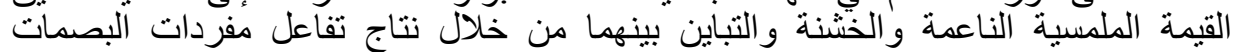

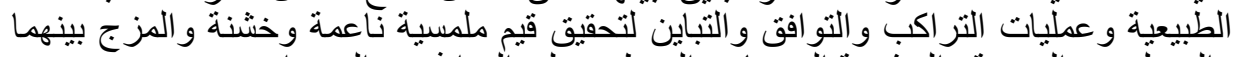

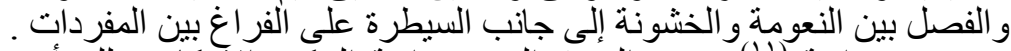

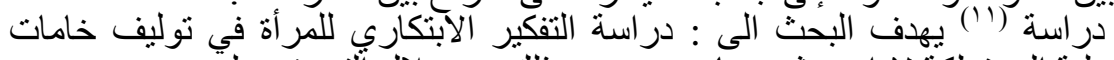

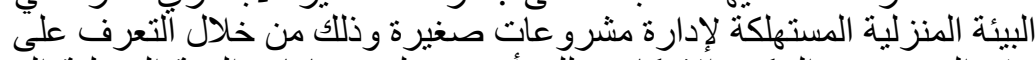

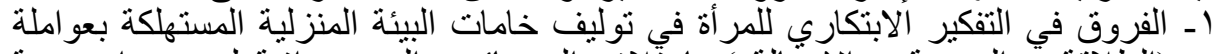

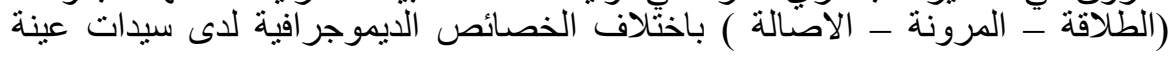




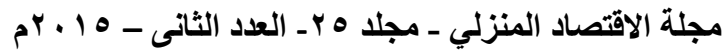

البحث (السن - الحالة الاجتماعية ـ المستوى التعليمي ـ الحالة الوظيفية ـ الدخل الثهري

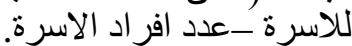

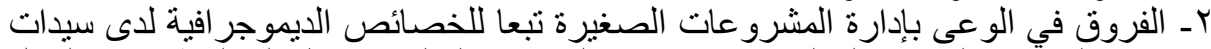

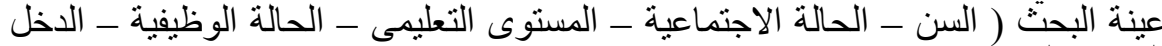
الثهرى للاسرة - عدد افر الد الاسرة)

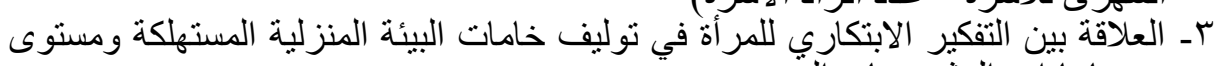

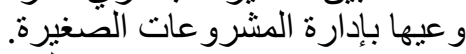

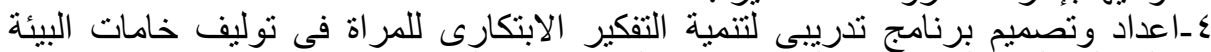

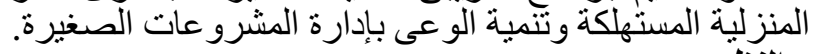
الاطار النظري : - النزئ

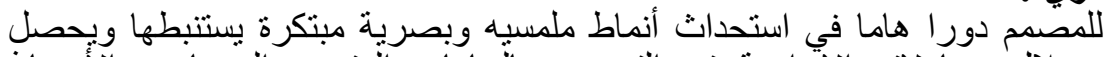

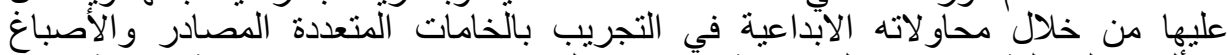

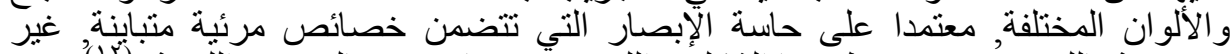

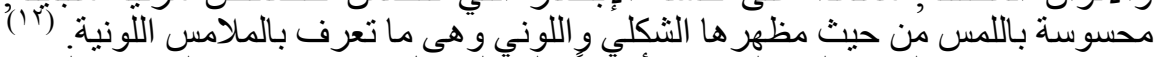

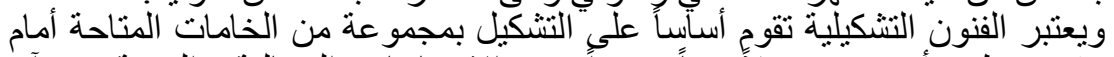

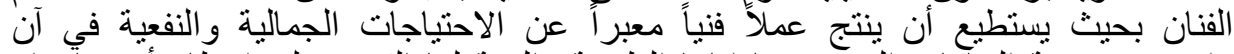

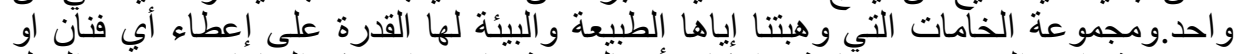

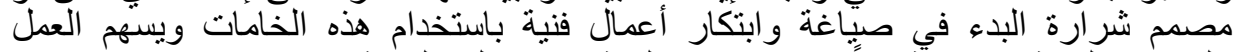

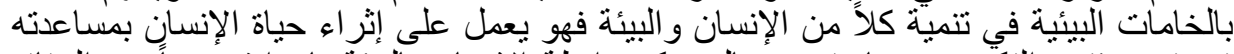

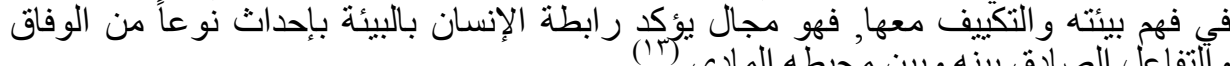
و آلتفاعل التصادق بينّه وبين محيطه المادي.

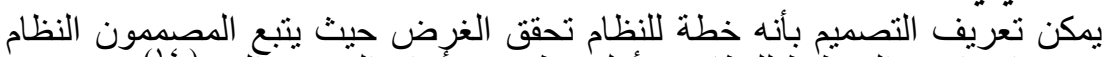
الابداعات التصميمية بينة

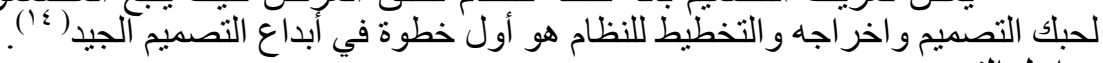

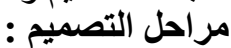
تمر عملية التصميم بعدة مر احل تتخلص في التالي: - - المرحلة التصميمية :وضع التصميم المتخيل على اللورق وتحديد الخامات والألوان

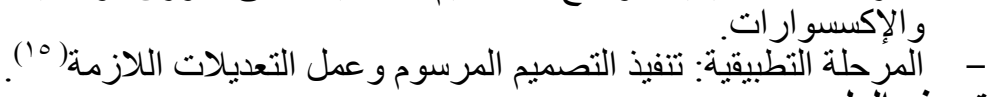
أحد عناصر التصميم ويعرف المعجم الوجيز بأنه إحدى الحواس الخمس الظاهرة تعريف الملمس حلة

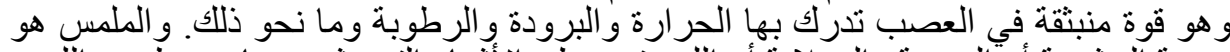

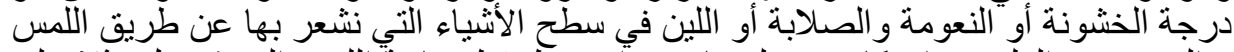

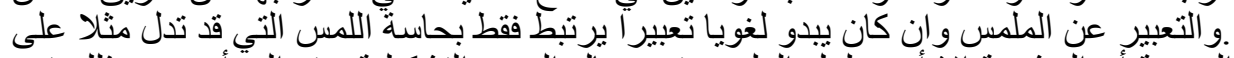

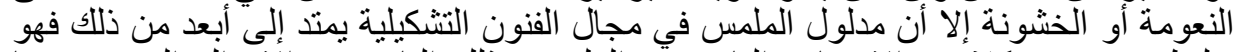

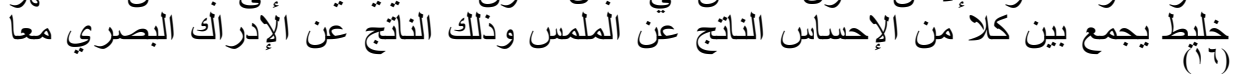

الاستكهام والتحليل وإعادة الصياغة: ويقصد بالتحليل وإعادة الصياغة هو ميلاد فكرة جديدة

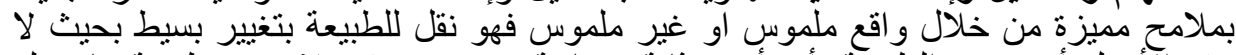

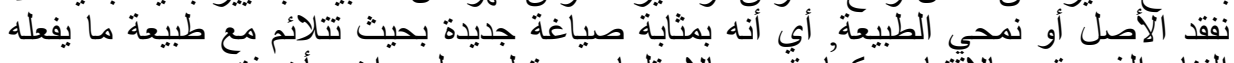

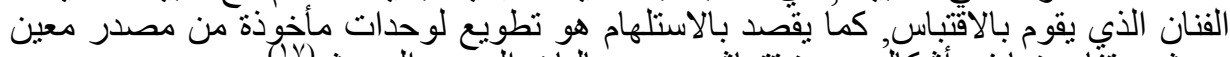

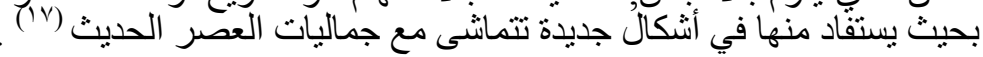




\section{مجلة الاقتصاد المنزلي - مجلد ه بـ العدد الثانى ـ 1 ـ بrم}

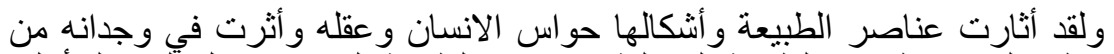

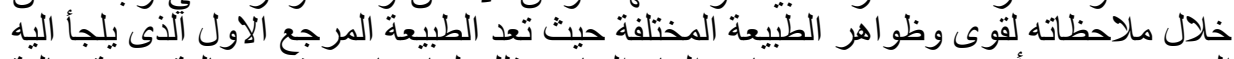

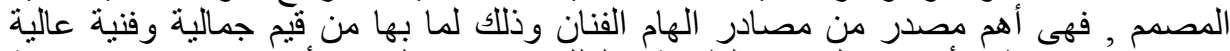

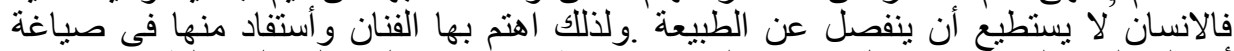

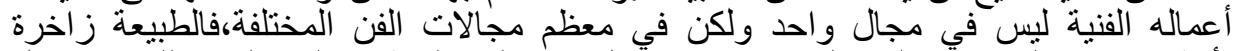

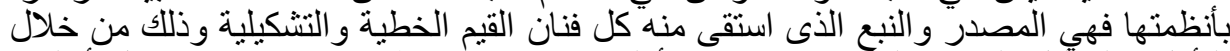

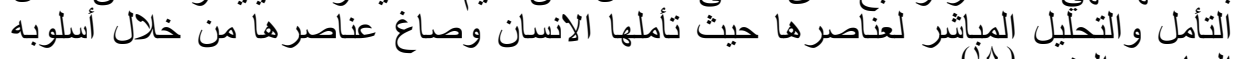

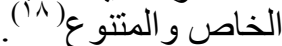

اندماج الخامات ودور ها في العمل الفني متعدد الأسطح:

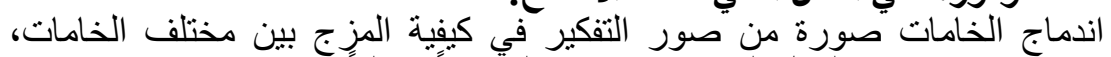

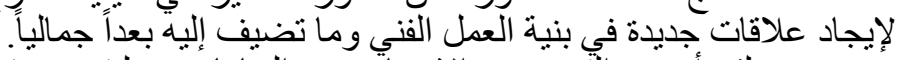

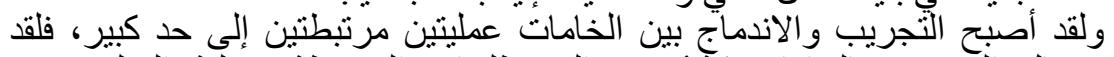

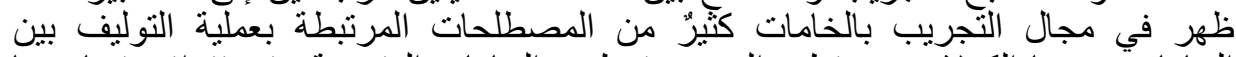

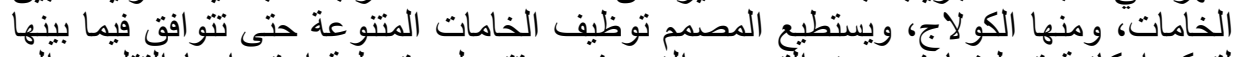

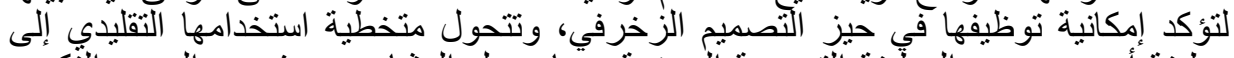

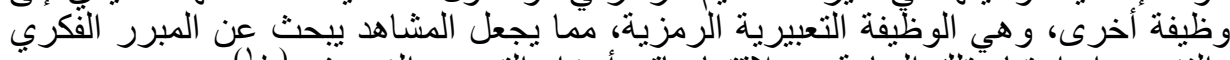

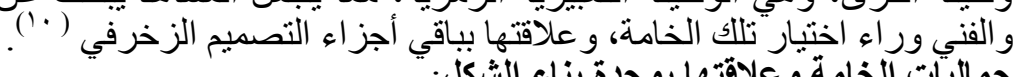
جماليّات الخامة وعلاقتها بوحدة بناء الثكان:

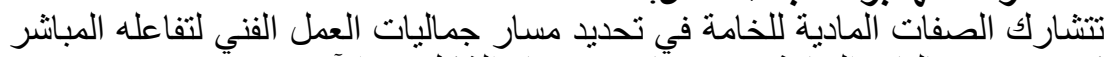

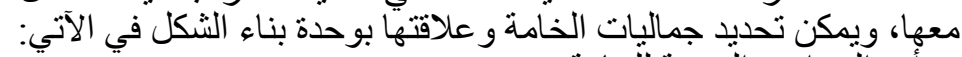
أ ـ الخواص الحسية للخامة.

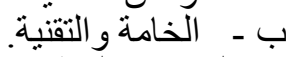
جـ المحتوي الوظيفي للخامة.

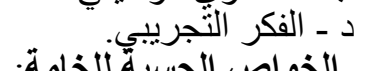
أ ـ الخواص الخسييّي للخامة:

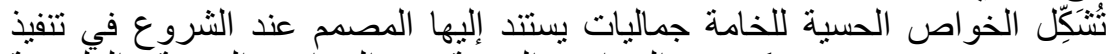

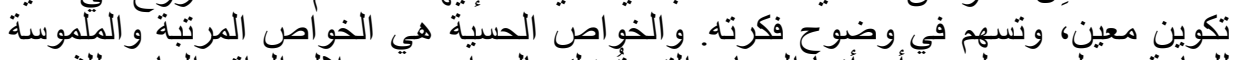

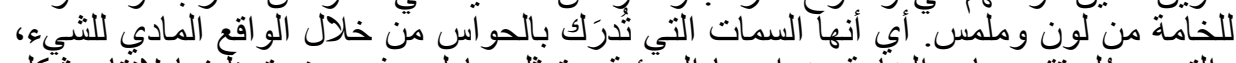

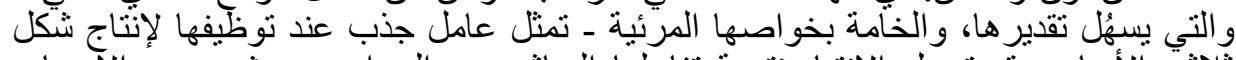

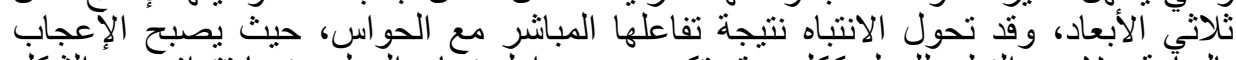

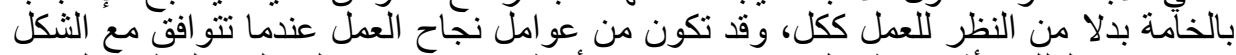

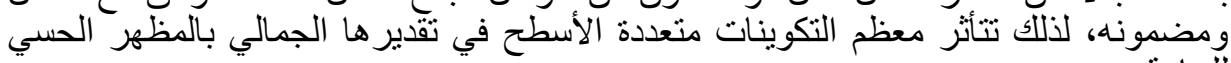

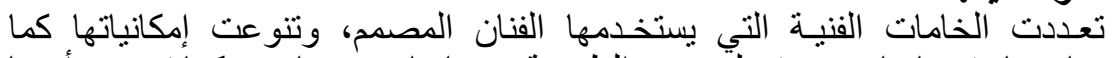

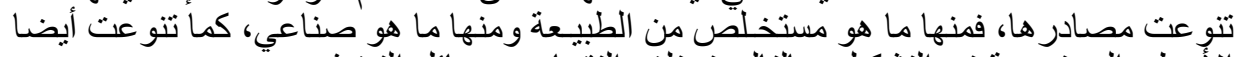

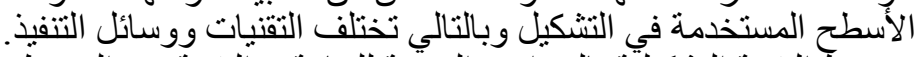

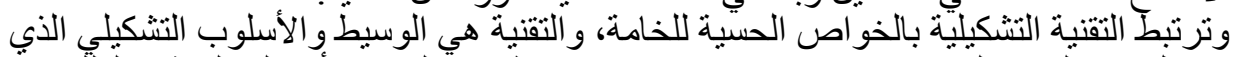

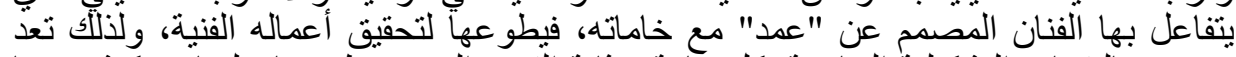

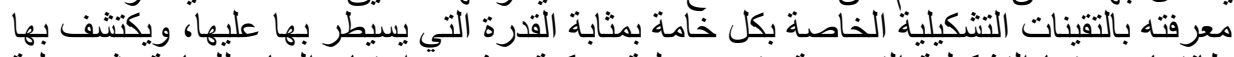

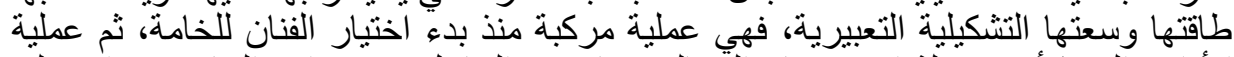

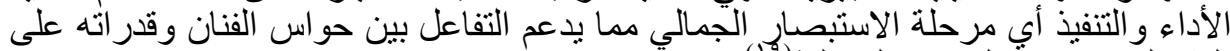

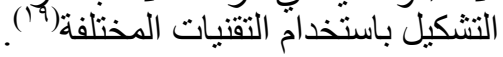




\section{مجلة الاقتصاد المنزلي ـ مجلد ه بـ العدد الثانى ـ 10 ب ب م}

كما تمثل الآثار التقنية على الخامات مثيراً بصرياً للمتنوق يمكن من خلاله ترجمة وقر اءة فكر

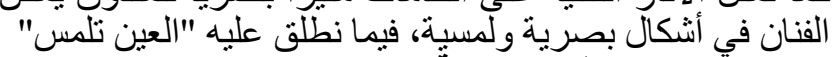
جـ المحتوى الوظيفي للخامةً:

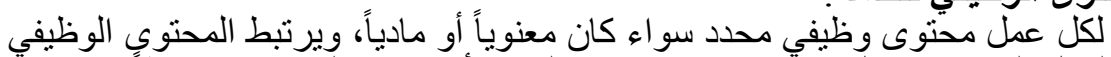

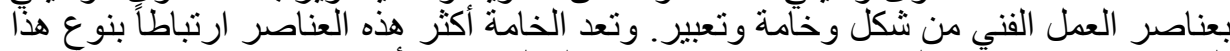

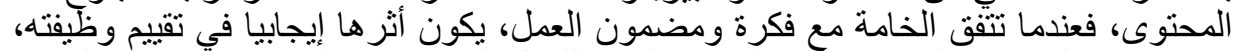

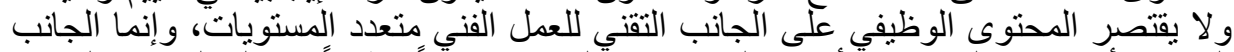

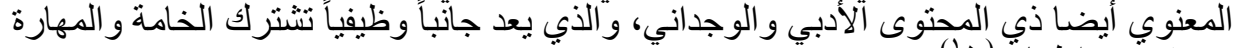

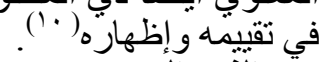

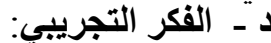

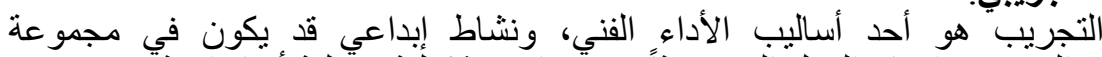
التخطيطات التي سبق إنجاز العمل الفني بحثاً عن جو انب تشكيلية مختلفة أو إبداعية جديدة فيدة، وقدا

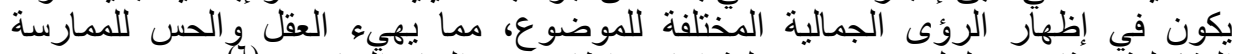

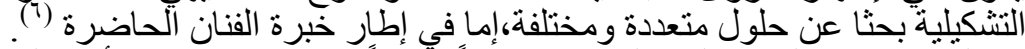

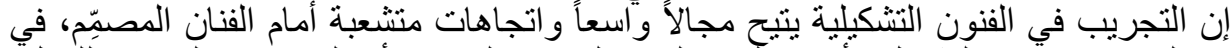

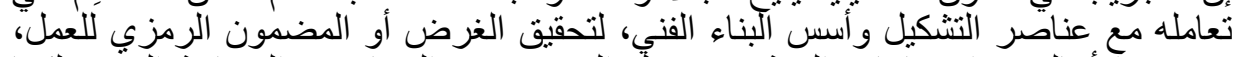

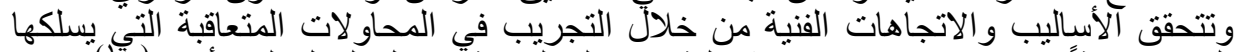

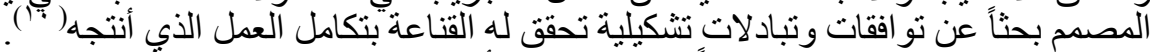

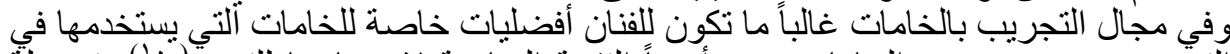

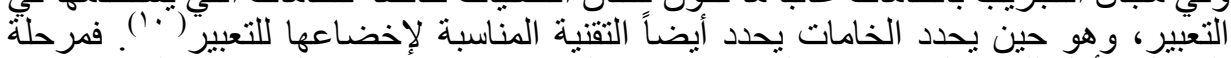

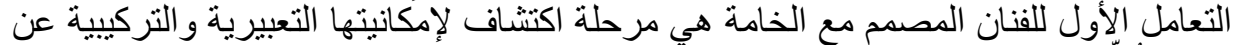

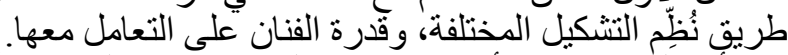

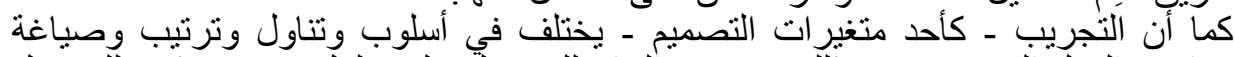

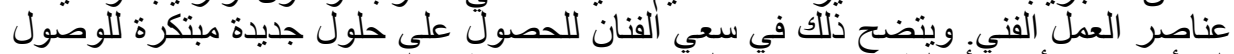

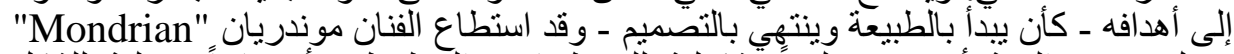

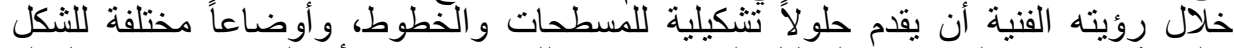

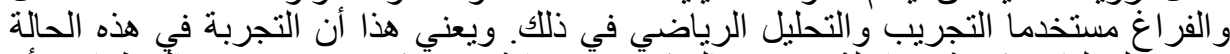

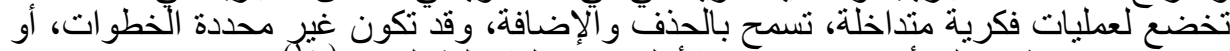

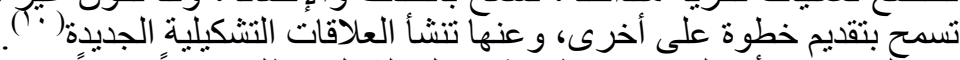

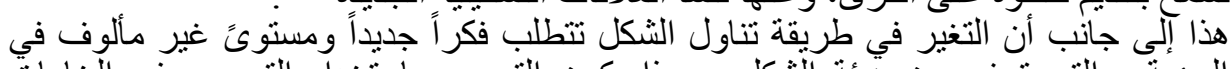

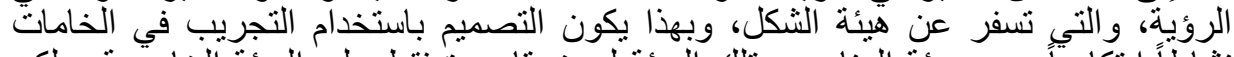

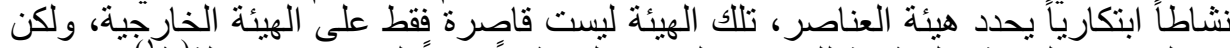

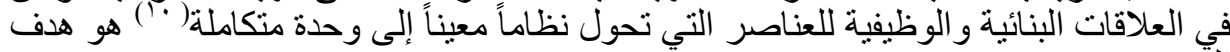

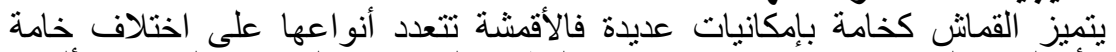

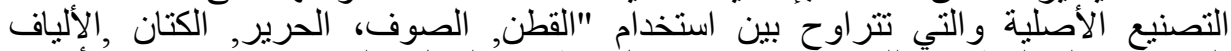

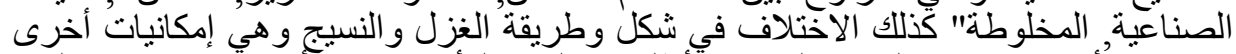

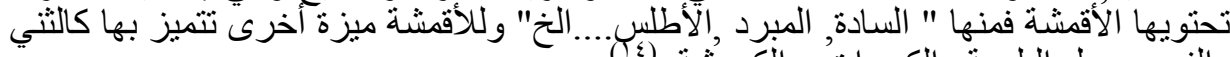

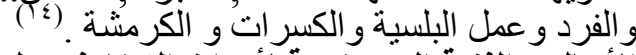

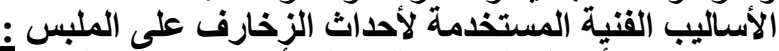

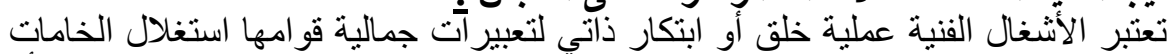

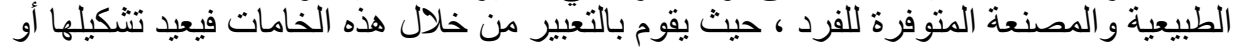




\section{مجلة الاقتصاد المنزلي - مجلد ه بـ العدد الثانى ـ 1 ـ بrم}

يقوم بالتوليف بينها مستخدما في ذللك الخبرات و المعلومات و المهارات المختلفة لتطويع هذه

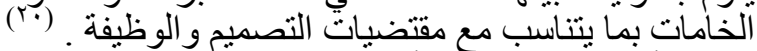
و هناك أنواع عديدة من الأشخال الفنية تسهم في إضفاء مظهر جذاب للملبس وتساعد في إبراز

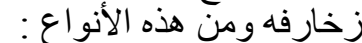

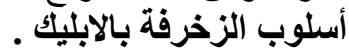
1 أسلوب الزخرفة بالتطريز. أسلوب الزخرفة بالطباعة. أقششة الثيفون :

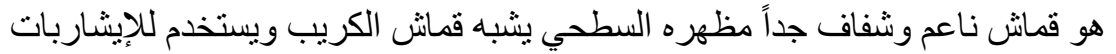

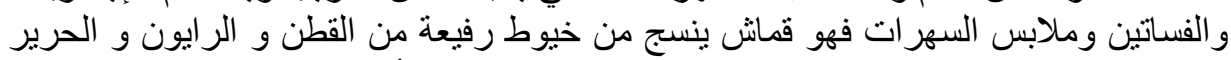

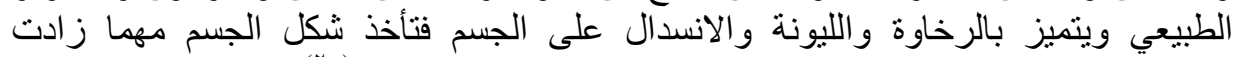

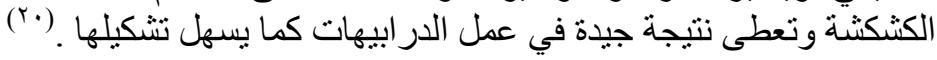
هو من الخامات الثفافة ولكنه أنقل من الثيفون وسطحه غير مستوى (محبب)

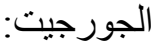

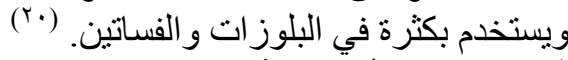
فن اختيار المرأة ألعاملة لملابسها الكها

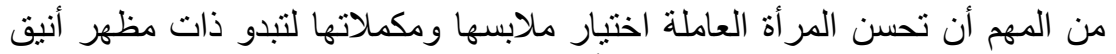

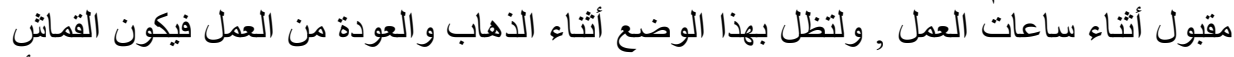

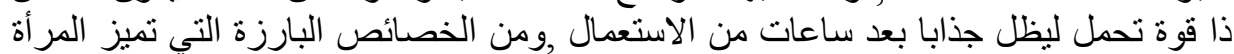

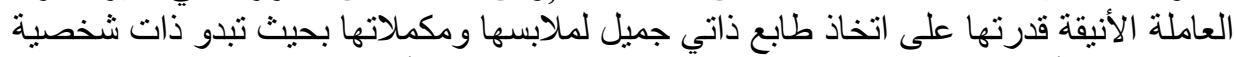

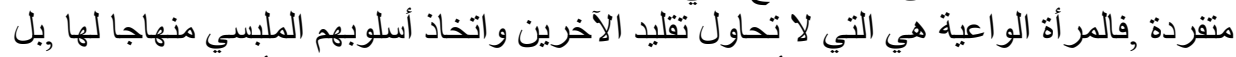

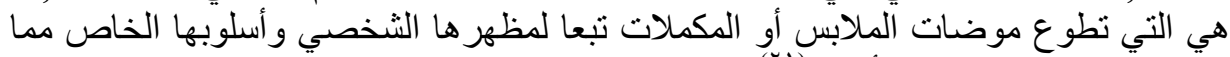

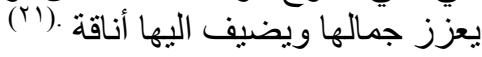
ثانيا:- الإطار العملي وقد نم تحديد الاتجاه الفني للمناظر الطبيعية وتحليل الهم الهم عناصرها

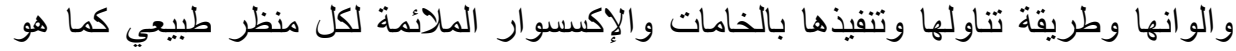

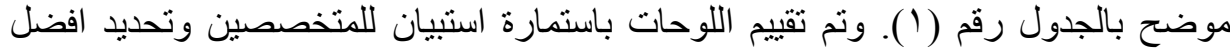
لوحات وتنفيذها على البلوزة الحريمي موضح بالتصميمات التوحات المنفذة. 
مجلة الاقتصاد المنزلي ـ مجلد ه ب ـ العدد الثانى ـ 1 ـ ب م

جدول رقم (1) يوضح التصميمات وطريقة التنفيذ والوحدات المقتبسة

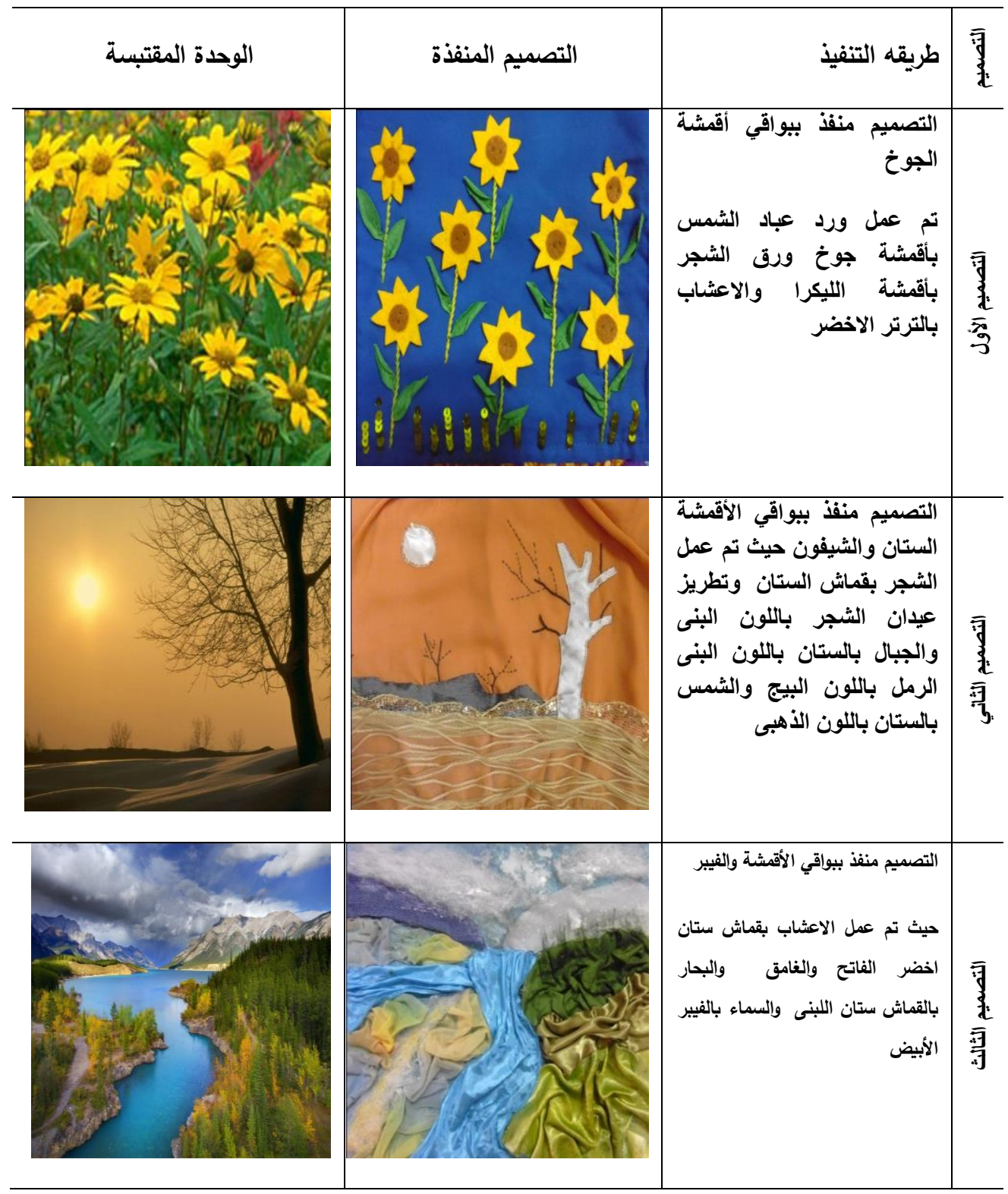


مجلة الاقتصاد المنزلي ـ مجلد هץ ـ العدد الثانى ـ 10 ـ ب م

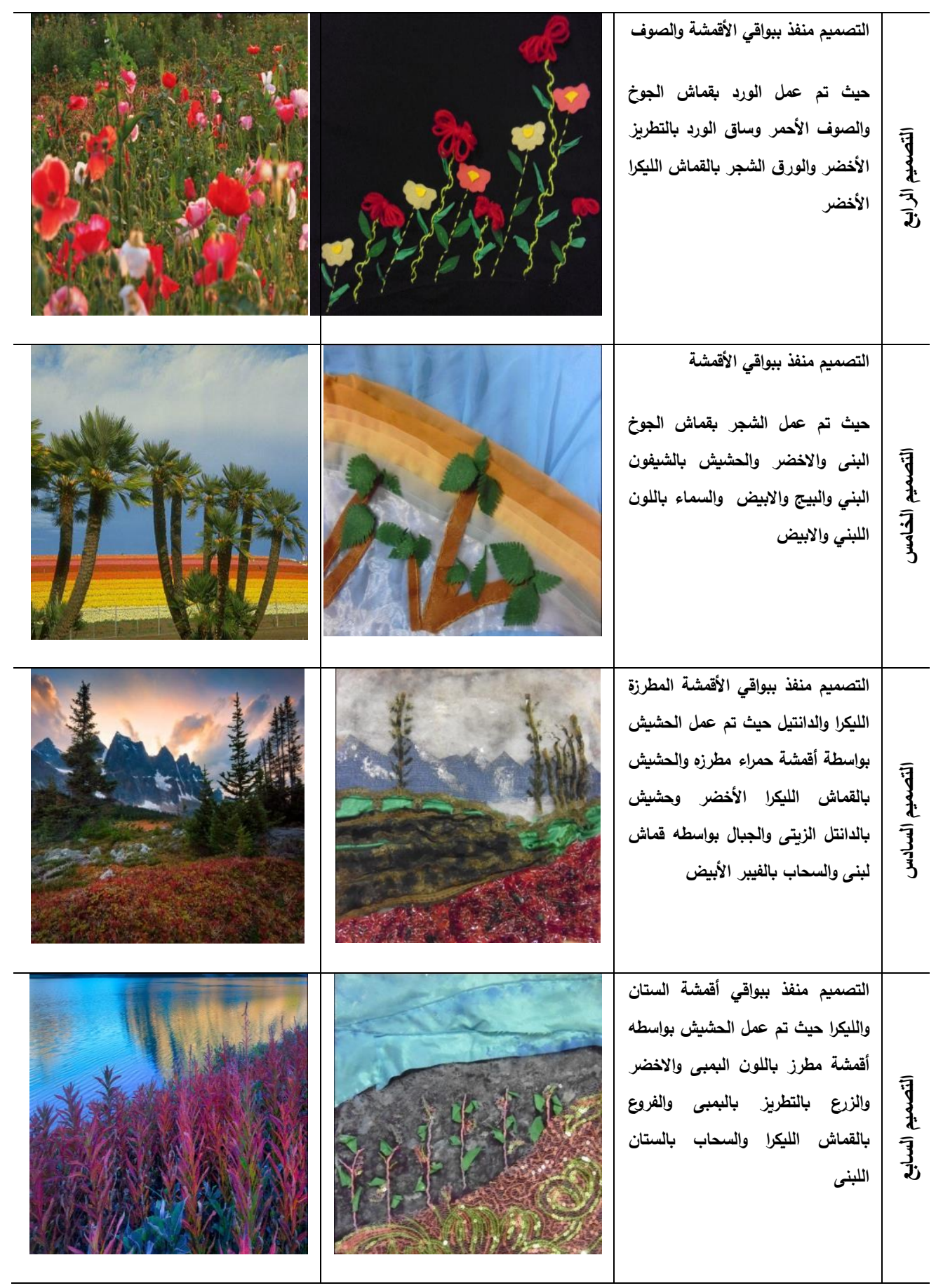


مجلة الاقتصاد المنزلي ـ مجلد Oبـ العدد الثانى ـ 10 ب بم

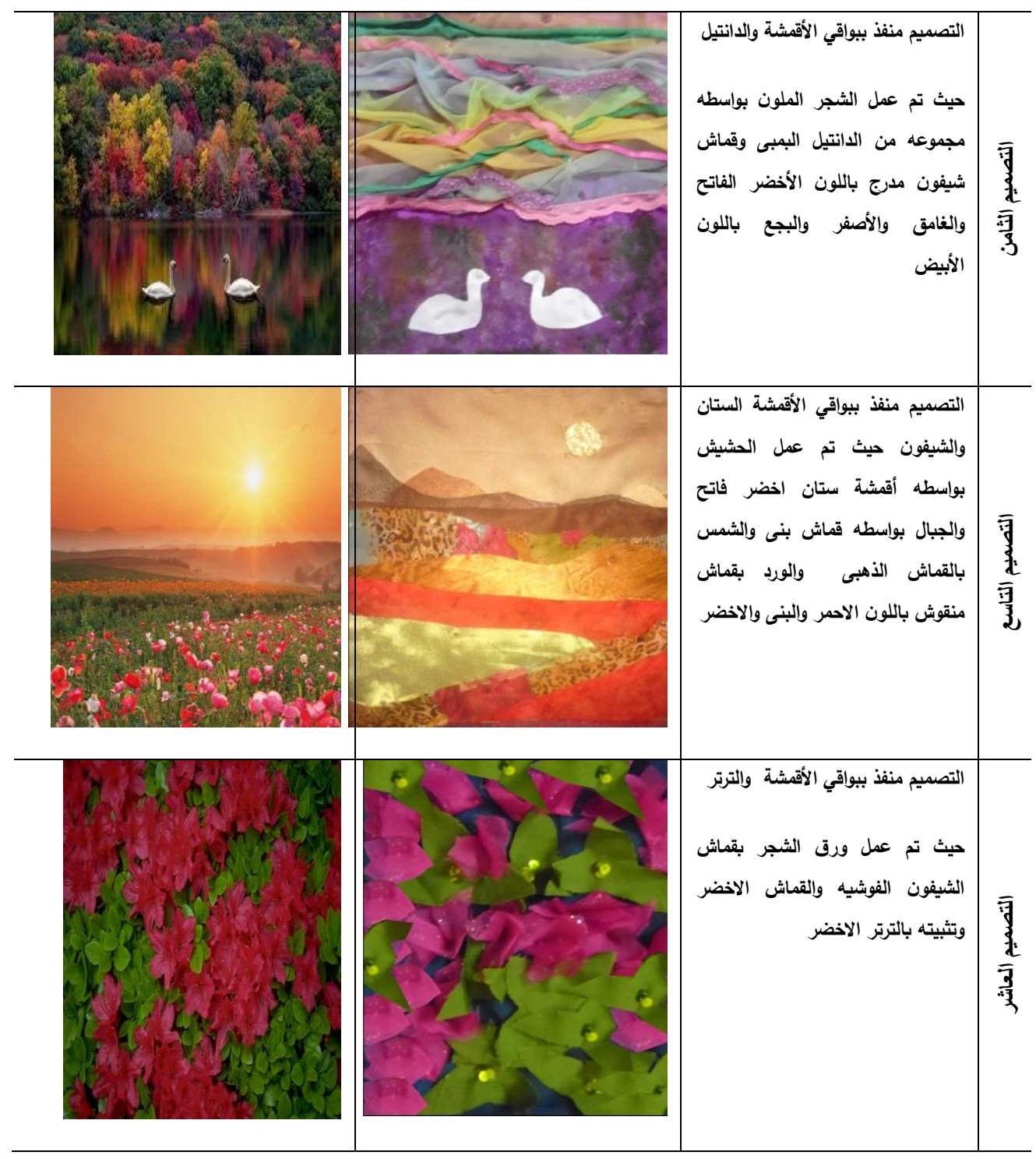

10. 
مجلة الاقتصاد المنزلي ـ مجلا ه rـ العدد الثانى ـ O 1 ـ r م

التصميمات المنفذة

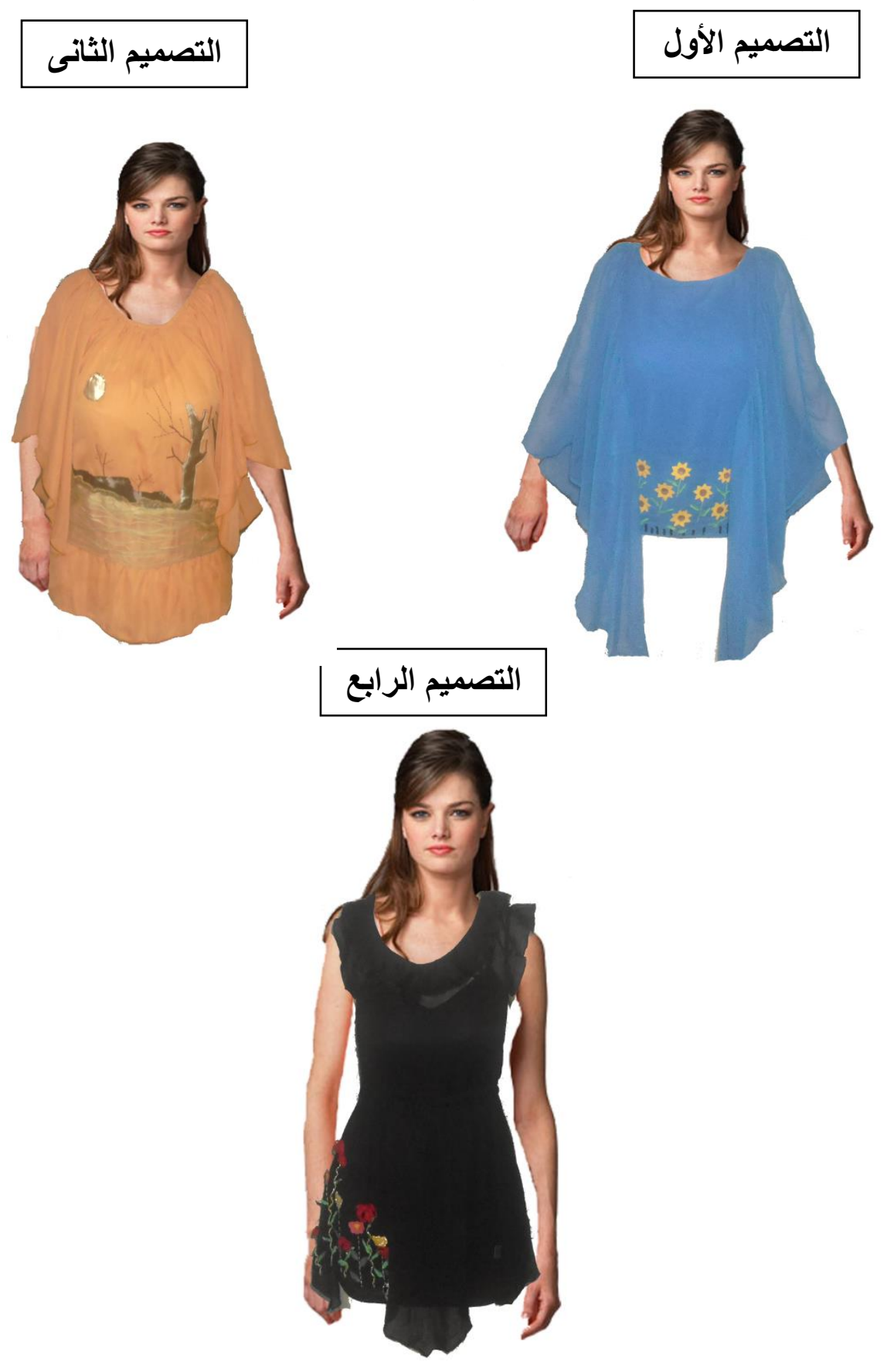

101 


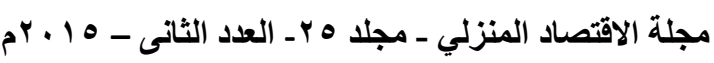
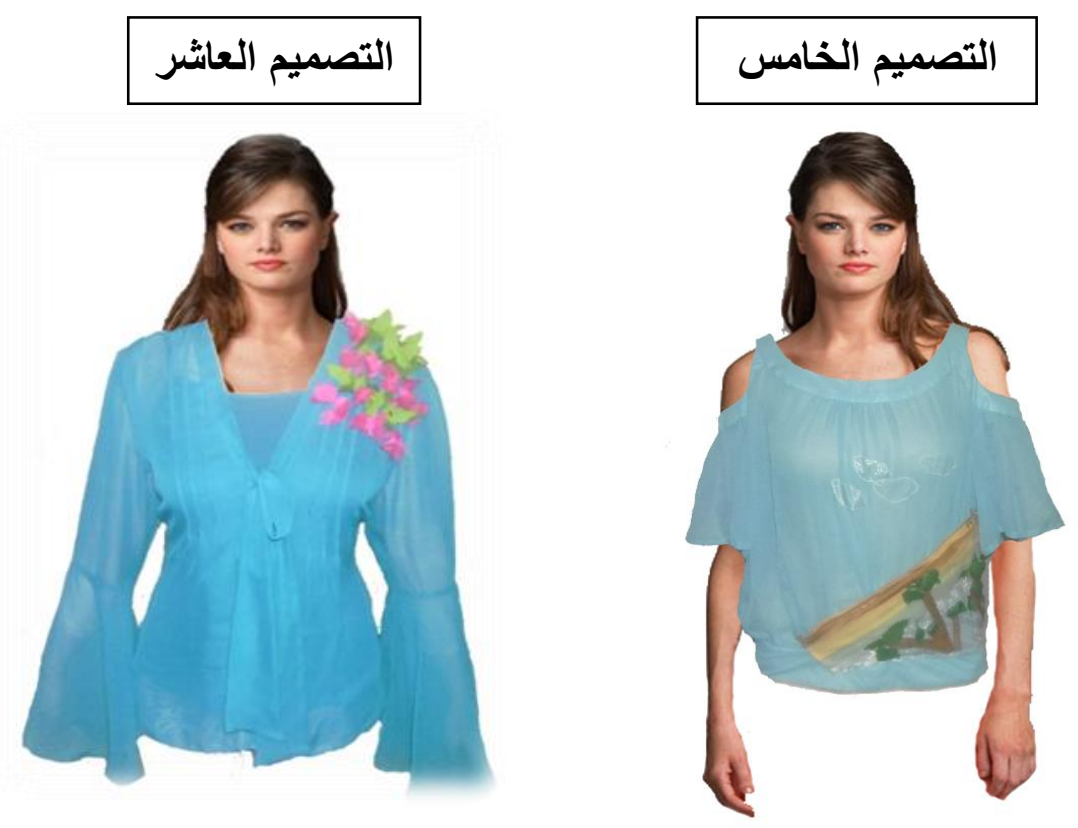

لتحقيق فروض البحث تم عمل معالجه احصائيه لنتائج الاستبيان للتصميمات محل

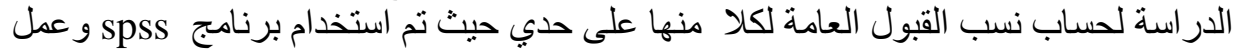

One way ANOVA اختبار

جدول رقم (r) يوضح النسب المئوية لملائمة للتصميمات المنفذة

\begin{tabular}{|c|c|c|c|c|c|c|c|c|c|c|c|c|c|c|c|}
\hline \multicolumn{3}{|c|}{ التصميم الخامس } & \multicolumn{3}{|c|}{ التصميم الرابع } & \multicolumn{3}{|c|}{ التصميم الثالث } & \multicolumn{3}{|c|}{ التصميم الثاني } & \multicolumn{3}{|c|}{ التصميم الأول } & \multirow[t]{2}{*}{ التصميمات } \\
\hline 变 & $\begin{array}{l}\frac{3}{2} 4 \\
\frac{2}{73}\end{array}$ & 卒 & 策; & $\begin{array}{l}\frac{3}{2} 7 \\
\frac{3}{3}\end{array}$ & $\frac{3}{2}$ & 等: & $\begin{array}{ll}\frac{3}{2} & 1 \\
\frac{3}{3} & 3\end{array}$ & 齐 & 祭 & $\begin{array}{l}\frac{3}{2} 1 \\
\frac{3}{3}\end{array}$ & $\frac{3}{2}$ & 踭, & $\begin{array}{l}\frac{3}{2} 1 \\
\frac{3}{3} 3\end{array}$ & 齐 & \\
\hline & $\begin{array}{l}1 . \\
\%\end{array}$ & $\begin{array}{l}q . \\
\%\end{array}$ & & $\begin{array}{l}r . \\
\%\end{array}$ & $\begin{array}{l}\wedge . \\
\%\end{array}$ & $\begin{array}{l}q . \\
\%\end{array}$ & \% & & & $\begin{array}{l}7 . \\
\%\end{array}$ & $\begin{array}{l}\varepsilon \\
\%\end{array}$ & & $\begin{array}{l}1 . \\
\%\end{array}$ & $\begin{array}{l}q . \\
\%\end{array}$ & التناصر التصميم التصميم \\
\hline & r. & $\wedge$. & & $r$ & $v$. & A. & r. & & & 0. & 0. & & $1 \cdot$ & 9. & ץ-تثناسب المساحات وشكل التصميم \\
\hline & $\%$ & $\%$ & & $\%$ & $\%$ & $\%$ & $\%$ & & & $\%$ & $\%$ & & $\%$ & $\%$ & \\
\hline & & $\begin{array}{l}1 . \\
\%\end{array}$ & & $\begin{array}{l}r \cdot \\
\%\end{array}$ & $\begin{array}{l}\wedge . \\
\%\end{array}$ & $\begin{array}{l}\text { A. } \\
\%\end{array}$ & $\begin{array}{l}r \cdot \\
\%\end{array}$ & & & $\begin{array}{l}\varepsilon \\
\%\end{array}$ & $\%$ & & $\begin{array}{l}\varepsilon \\
\%\end{array}$ & $\%$ & بـتنتاغة ملامس الخامات مع \\
\hline & r. & $\lambda$. & & $r$ r. & v. & 9. & 1. & & & $\frac{1}{1 .}$ & 9. & & $r$. & v. & أ-ملائمة الثأثير اللونى و علاقتها \\
\hline & $\%$ & $\%$ & & $\%$ & $\%$ & $\%$ & $\%$ & & & $\%$ & $\%$ & & $\%$ & $\%$ & 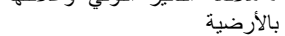 \\
\hline & r. & $\mathrm{v}$ & & $r$ & $\hat{A}$. & 7. & $\varepsilon \cdot$ & & & & $1 \ldots$ & & $r \dot{r}$ & $\begin{aligned} v \cdot \\
0\end{aligned}$ & 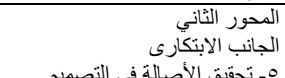 \\
\hline & $\frac{r}{r .}$ & $\frac{10}{\lambda .}$ & & 1. & 9. & A. & r. & & & 1. & 9. & & 1. & 9. & 7 ـ تحقيق الحداثة في التصعيد \\
\hline & $\%$ & $\%$ & & $\%$ & $\%$ & $\%$ & $\%$ & & & $\%$ & $\%$ & & $\%$ & $\%$ & \\
\hline & 0. & 0. & & 1. & 9. & A. & $r$. & & & $r$. & A. & & & $1 \ldots$ & Y- ب- تحقيق الثميز في التصميم \\
\hline & $\%$ & $\%$ & & $\%$ & $\%$ & $\%$ & $\%$ & & & $\%$ & $\%$ & & & $\%$ & \\
\hline 1. & $r$. & 7. & & $r$. & A. & $\mathrm{ve}$ & $r$. & & & T. & 9. & & 1. & 9. & ^ــ تحقيق النمطية في التصميج \\
\hline$\%$ & $\%$ & $\%$ & & $\%$ & $\%$ & $\%$ & $\%$ & & & $\%$ & $\%$ & & $\%$ & $\%$ & \\
\hline
\end{tabular}




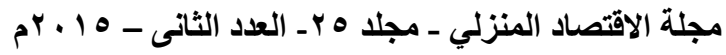

\begin{tabular}{|c|c|c|c|c|c|c|c|c|c|c|c|c|c|c|c|}
\hline \multicolumn{3}{|c|}{ التصميم العاشر } & \multicolumn{3}{|c|}{ التصميم التاسع } & \multicolumn{3}{|c|}{ التصميم الثامن } & \multicolumn{3}{|c|}{ التصميم السابع } & \multicolumn{3}{|c|}{ التصميم السادس } & \multirow[t]{2}{*}{ التصميمات } \\
\hline 無 & $\frac{3}{3} 1$ & 齐 & 管: & $\frac{3}{3} \frac{1}{3}$ & 卒 & 無 & $\begin{array}{ll}\frac{3}{2} & 1 \\
\frac{3}{3} & 3\end{array}$ & 齐 & 等: & $\begin{array}{l}\frac{3}{2} 4 \\
\frac{3}{3}\end{array}$ & 齐 & 無 & $\begin{array}{l}\frac{1}{2} 4 \\
\frac{3}{3}-1\end{array}$ & 齐 & \\
\hline & & $\begin{array}{l}1 . \\
\%\end{array}$ & $\begin{array}{l}\varepsilon \\
\%\end{array}$ & $\begin{array}{l}r \cdot \\
\%\end{array}$ & $\begin{array}{l}1 . \\
\%\end{array}$ & $\begin{array}{l}r \cdot \\
\%\end{array}$ & $\begin{array}{l}v \cdot \\
\%\end{array}$ & $\begin{array}{l}1 . \\
\%\end{array}$ & $\begin{array}{l}\varepsilon \\
\%\end{array}$ & $\begin{array}{l}7 . \\
\%\end{array}$ & & $\begin{array}{l}\varepsilon \\
\%\end{array}$ & $\begin{array}{l}\circ \\
\%\end{array}$ & $\begin{array}{l}10 \\
\%\end{array}$ & 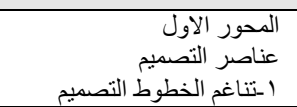 \\
\hline & 1. & $\%$ & 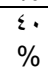 & $\begin{array}{l}7 \cdot \\
\%\end{array}$ & & $\begin{array}{l}7 \cdot \\
\%\end{array}$ & $\begin{array}{l}r \cdot \\
\%\end{array}$ & $\%$ & $\varepsilon$ & $\begin{array}{l}\ddot{\circ} \\
\%\end{array}$ & 1. & $\begin{array}{l}0 . \\
\%\end{array}$ & $\begin{array}{l}\ddot{0} \\
\%\end{array}$ & & التصيميب \\
\hline & i. & $\begin{array}{l}9 \cdot \\
\%\end{array}$ & $\begin{array}{l}7 . \\
\%\end{array}$ & $\begin{array}{l}\varepsilon \cdot \\
\%\end{array}$ & & $\begin{array}{l}v \cdot \\
\%\end{array}$ & 10 & $\begin{array}{l}r \cdot \\
\%\end{array}$ & $\begin{array}{l}7 . \\
\%\end{array}$ & $\dot{r}$ & $1 \%$ & $\hat{\%}$. & r. & & rكضتناغم ملامس الخامات مع \\
\hline & 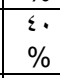 & $\begin{array}{l}7 . \\
\%\end{array}$ & $\begin{array}{l}v \cdot \\
\%\end{array}$ & $\begin{array}{l}\% \\
\% \\
\end{array}$ & $\begin{array}{l}1 \cdot \\
\%\end{array}$ & $\begin{array}{l}1 . \\
\%\end{array}$ & & $\%$ & $\hat{\%}$ & $\%$ & $\%$ & $\%$ & $\varepsilon$ & & و علاقلائمة بالأرضية التأثيّر $\quad$ اللونى \\
\hline & $\begin{array}{l}r \cdot \\
\%\end{array}$ & $\begin{array}{l}\wedge . \\
\%\end{array}$ & $\begin{array}{l}r . \\
\%\end{array}$ & $\begin{array}{l}7 . \\
\%\end{array}$ & $\begin{array}{l}1 \cdot \\
\%\end{array}$ & $\begin{array}{l}\varepsilon \\
\%\end{array}$ & $\begin{array}{l}\circ \\
\%\end{array}$ & $\begin{array}{l}1 . \\
\%\end{array}$ & $\begin{array}{l}\varepsilon \\
\%\end{array}$ & $\begin{array}{l}7 . \\
\%\end{array}$ & & $\begin{array}{l}v \cdot \\
\%\end{array}$ & $\begin{array}{l}r \cdot \\
\%\end{array}$ & & 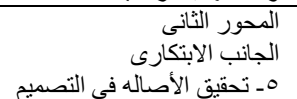 \\
\hline & 1. & $\begin{array}{l}9 . \\
\%\end{array}$ & $\begin{array}{l}0 . \\
\%\end{array}$ & $\begin{array}{l}r \cdot \\
\%\end{array}$ & r. & $\begin{array}{l}0 . \\
\%\end{array}$ & 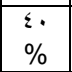 & \% & q. & \%) & & $\begin{array}{l}\hat{\kappa} \cdot \\
\%\end{array}$ & r. & & آـ تحقيق الحداثه فى التصميح \\
\hline & & $\begin{array}{l}1 \ldots \\
\%\end{array}$ & $\begin{array}{l}\wedge . \\
\%\end{array}$ & $\begin{array}{l}1 \cdot \\
\%\end{array}$ & $\begin{array}{l}1 . \\
\%\end{array}$ & $\begin{array}{l}v \cdot \\
\%\end{array}$ & $\begin{array}{l}1 \% \\
\%\end{array}$ & $\begin{array}{l}r \cdot \\
\%\end{array}$ & $\begin{array}{l}\lambda . \\
\%\end{array}$ & $\begin{array}{l}r \cdot \\
\%\end{array}$ & & $\begin{array}{l}9 . \\
\%\end{array}$ & $\begin{array}{l}1 \dot{\%} \\
\%\end{array}$ & & V- تحقيق التميز فى التصميم \\
\hline & i. & $\begin{array}{l}9 . \\
\%\end{array}$ & $\begin{array}{l}\gamma \cdot \\
\%\end{array}$ & $\begin{array}{l}r \cdot \\
\%\end{array}$ & $\begin{array}{l}1 . \\
\%\end{array}$ & $\begin{array}{l}A \cdot \\
\%\end{array}$ & & $\begin{array}{l}r \\
\%\end{array}$ & $\begin{array}{l}\lambda \cdot \\
\%\end{array}$ & $\begin{array}{l}r \cdot \\
\%\end{array}$ & & $\begin{array}{ll}\hat{\mu} \\
\%\end{array}$ & $\begin{array}{l}r \cdot \\
\%\end{array}$ & & ^ــ تحقيق النمطية فى التصميج \\
\hline
\end{tabular}
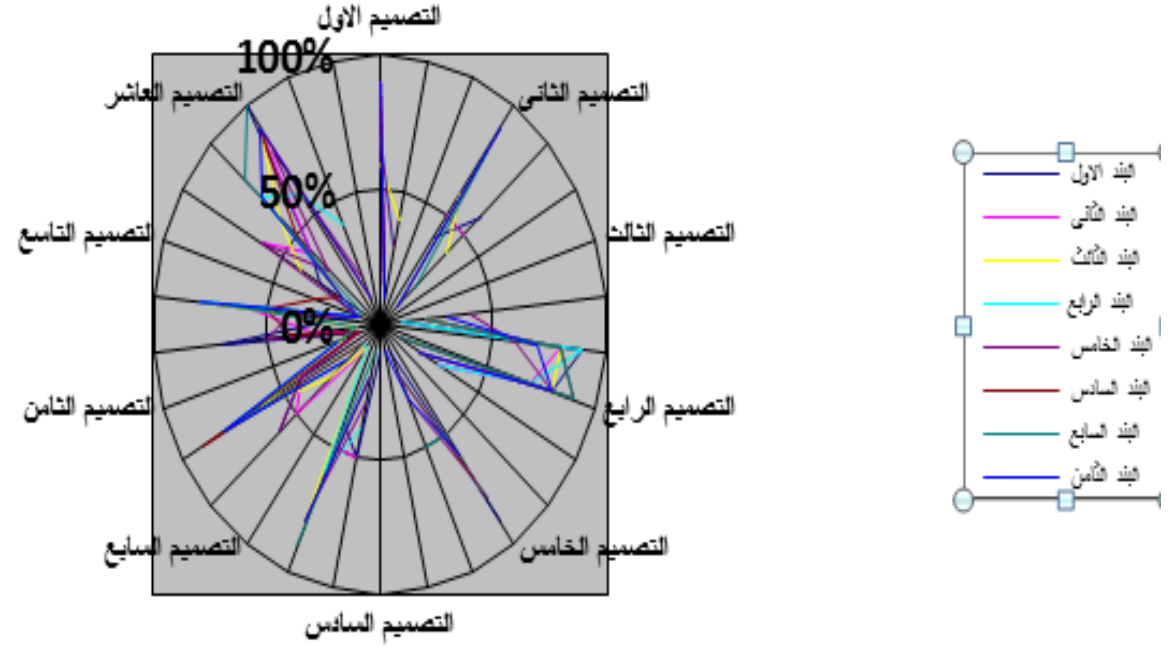

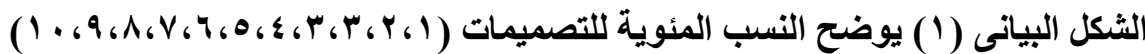


مجلة الاقتصاد المنزلي ـ مجلد Oبـ العدد الثانى ـ 10 ب بم

المحور الأول : عناصر التصميم

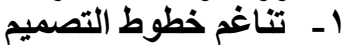
جدول (r) تحليل التباين لارجات المحكمين

\begin{tabular}{|c|c|c|c|c|c|}
\hline الدلالة & قيمة (ف) & لدرجات & المربعات & المزبعوات & تناغم خطوط التصميم \\
\hline \multirow{3}{*}{ 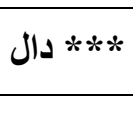 } & \multirow{2}{*}{$1 \% .1 \cdot 7$} & 9 & $\varepsilon .1 .7$ & 57.97 & بين المجموعات \\
\hline & & 9 . & & TA. & داخل المجموعات \\
\hline & & 99 & & 70.17 & المجموع \\
\hline
\end{tabular}

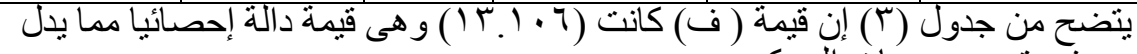

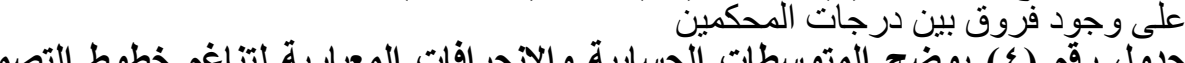
جلول رقم (؛) يوضح المتوسطات الحسابية والانحرافات المعيارية لتناغم خطوط التصميم

\begin{tabular}{|c|c|c|}
\hline تتاغم خطوط التصميم & \multicolumn{2}{|c|}{ التصميمات } \\
\hline $\operatorname{ar}^{r} \cdot 9 \pm$ & المتوسط & \multirow{2}{*}{ التصميم الأول } \\
\hline . MT & الانحر اف & \\
\hline$a^{r} . \varepsilon \pm$ & المتوسط & \multirow{2}{*}{ التصميم الثاني } \\
\hline$\because V$ & الانحر اف & \\
\hline b'. $0^{\circ} \pm$ & المتوسط & \multirow{2}{*}{ التصميم الثالث } \\
\hline $85 \cdot$. & الانحر اف & \\
\hline$a^{r} \cdot \wedge_{ \pm}$ & المتوسط & \multirow{2}{*}{ التصميم الر ابع } \\
\hline $42 \cdot$ & الانحر اف & \\
\hline$a^{r} \cdot 9 \pm$ & المتوسط & \multirow{2}{*}{ التصميم الخامس } \\
\hline.$M$ & الانحر اف & \\
\hline b'. $\vee \pm$ & المتوسط & \multirow{2}{*}{ التصميم السادس } \\
\hline $.7 \mathrm{~V}$ & الانحر اف & \\
\hline b).. \pm & المتوسط & \multirow{2}{*}{ التصميم السابع } \\
\hline .01 & الانحر اف & \\
\hline b) $.9 \pm$ & المتوسط & \multirow{2}{*}{ التصميم الثامن } \\
\hline $56 \cdot$ & الانحر اف & \\
\hline b). ${ }^{\circ} \pm$ & المتوسط & \multirow{2}{*}{ التصميم التاسع } \\
\hline$\because V$ & الانحر اف & \\
\hline$a^{\mu} \pm$ & المتوسط & \multirow{2}{*}{ التصميم العاشر } \\
\hline . & الانحر اف & \\
\hline
\end{tabular}


مجلة الاقتصاد المنزلي ـ مجلد Oبـ العدد الثانى ـ 10 ب بم

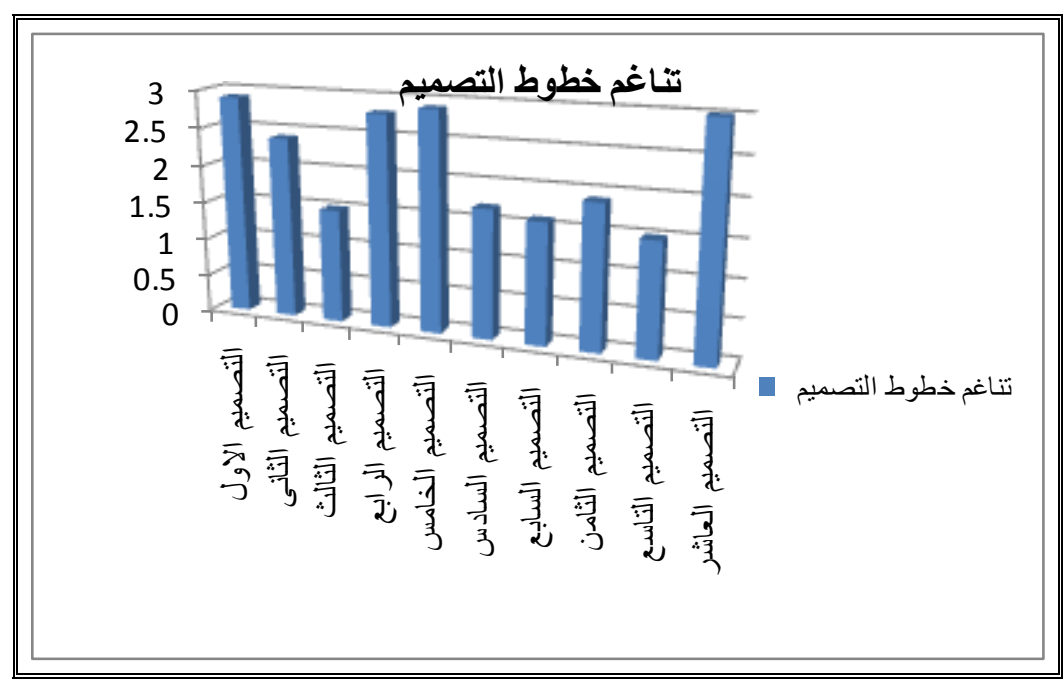

الثكل البياني (ץ) يوضح الفروق بين التصميمات المختلفة وتناغم خطوط التصميم وفقا

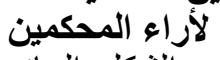

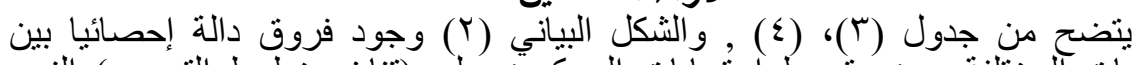

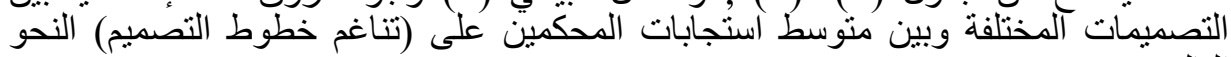

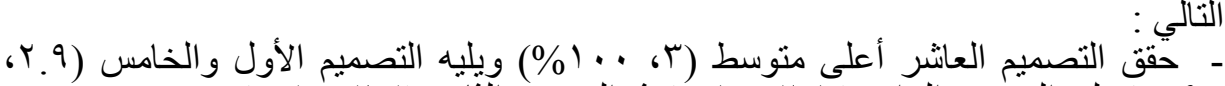

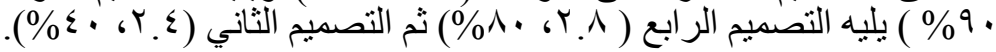

\begin{tabular}{|c|c|c|c|c|c|}
\hline & & & & التصميم التم المي & لدول (ث) تحليل المساحات \\
\hline الدلالة & قيمة (ف) & الدرجات & المربعات & المزبعوت & تنتاسب المساحات \\
\hline \multirow{3}{*}{ 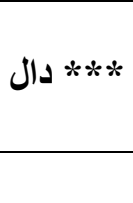 } & \multirow{2}{*}{$1 \leqslant . \wedge \leqslant \varepsilon$} & 9 & r.AI & $r \varepsilon . r q$ & بين المجموعات \\
\hline & & 9. &.$r 07$ & YT.I & داخل المجموعات \\
\hline & & 99 & & ov.rq & المجموع \\
\hline
\end{tabular}


مجلة الاقتصاد المنزلي - مجلد ه بـ العدد الثانى ـ 10 ـ ب م

جدول رقم( ) يوضح المتوسطات الحسابية والانحرافات المعيارية تناسب المساحات وشكل

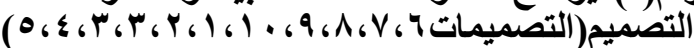

\begin{tabular}{|c|c|c|}
\hline تناسب المساحات & \multicolumn{2}{|c|}{ التصميمات } \\
\hline وبح ألصقيم & المت سط & \multirow{2}{*}{ التصميم الأول } \\
\hline$\frac{. r 1}{. \mu 1}$ & الانحر اف & \\
\hline $\operatorname{ar}^{\top} 0_{ \pm}$ & المتوسط & \multirow{2}{*}{ التصميم الثاني } \\
\hline. $.0 Y$ & الانحر اف & \\
\hline b! $. \wedge \pm$ & المتوسط & \multirow{2}{*}{ التصميم الثالث } \\
\hline $42 \cdot$. & الانحر اف & \\
\hline$a^{r} . V_{ \pm}$ & المتوسط & \multirow{2}{*}{ التصميم الر ابع } \\
\hline$\Lambda 4 \cdot$ & الانحر اف & \\
\hline $\mathrm{a}^{\Upsilon} . \wedge \pm$ & المتوسط & \multirow{2}{*}{ التصميم } \\
\hline $42 \cdot$. & الانحر اف & \\
\hline b $^{1} .{ }^{\circ} \pm$ & المتوسط & \multirow{2}{*}{ التصميم السادس } \\
\hline $.0 Y$ & الانحر اف & \\
\hline$b^{\prime} . \vee \pm$ & المتوسط & \multirow{2}{*}{ التصميم السابع } \\
\hline$\because .7 \mathrm{~V}$ & الانحر اف & \\
\hline b!. $.0 \pm$ & المتوسط & \multirow{2}{*}{ التصميم الثامن } \\
\hline $7 \cdot$. & الانحر اف & \\
\hline b).7 \pm & المتوسط & \multirow{2}{*}{ التصميم التاسع } \\
\hline$\because 0$ & الانحر اف & \\
\hline$a^{r} .9 \pm$ & المتوسط & \multirow{2}{*}{ التصميم العاثر } \\
\hline 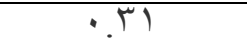 & الانحر اف & \\
\hline
\end{tabular}

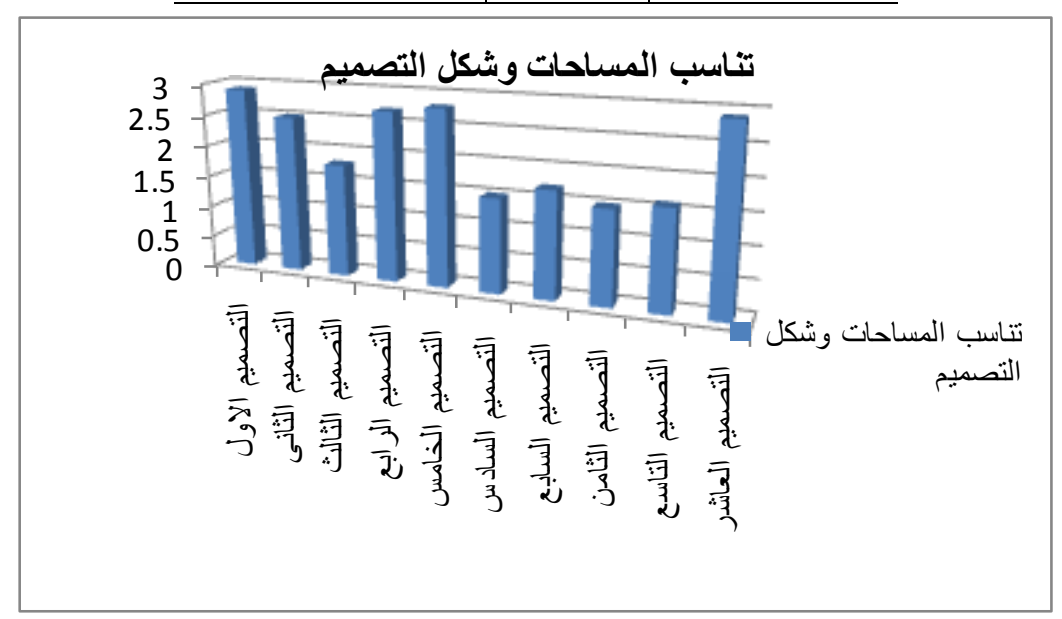

الثكل البياني (ّ) يوضح الفروق بين التصميمات المختلفة و تناسب المساحات وشكل التصميم وفقا لأراء المحكمين التمنين 


$$
\text { مجلة الاقتصاد المنزلي - مجلد هب ـ العدد الثانى ـ } 10 \text { ب r م }
$$

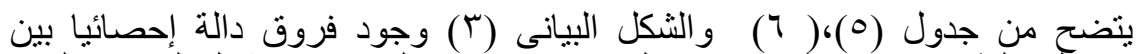
التصميمات المختلفة وبين منوسط استجابات المحكمين وتناسب المساحات وشكل التصميم النحو

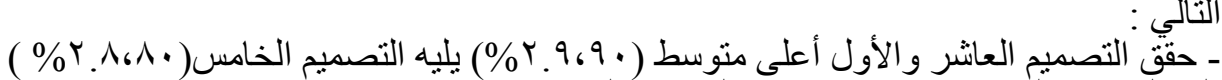

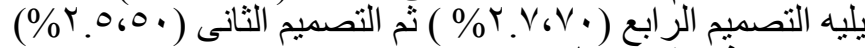

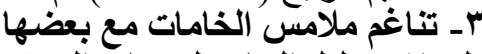
جدول (V) تحليل التباين لاغرجات ألمحكمين

\begin{tabular}{|c|c|c|c|c|c|}
\hline الالالة & قيمة (ف) & الرجية & المربعات & المزبعوت & تخاغم ملاتمس مع \\
\hline \multirow{3}{*}{ 柆*** دال } & \multirow[b]{2}{*}{ Tr. $\leqslant 70$} & 9 & ๆ. $\varepsilon \wedge$ & $0 \leqslant . \leqslant$ & بين المجموعات \\
\hline & & 9. &. TOV & YT.Y & المجموعات \\
\hline & & 99 & & $V V .7 \varepsilon$ & المجموع \\
\hline
\end{tabular}

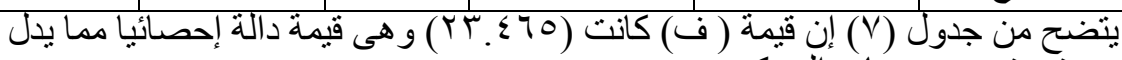
على وجود فروق بين درجات المحكمين

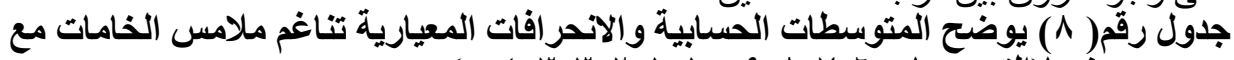

\begin{tabular}{|c|c|c|}
\hline تثاغم ملامس & \multicolumn{2}{|c|}{ التصميمات } \\
\hline ar. $7 \pm$ & المتوسط & \multirow{2}{*}{ التصميم الأول } \\
\hline .01 & الانحر اف & \\
\hline ar. $7 \pm$ & المتوسط & \multirow{2}{*}{ التصميم الثاني } \\
\hline .01 & الانحر اف & \\
\hline$b^{\prime} .1 \pm$ & المتوسط & \multirow{2}{*}{ التصميم الثالث } \\
\hline $1 \cdot \varphi^{\mu}$ & الانحر اف & \\
\hline $\mathrm{ar}^{r} . \wedge \pm$ & المتوسط & \multirow{2}{*}{ التصميم الر ابع } \\
\hline $42 \cdot$. & الانحر اف & \\
\hline $\mathrm{a}^{\tilde{\mu} \pm}$ & المنوسط & \multirow{2}{*}{ التخامسبم } \\
\hline$\cdot$ & الانحر اف & \\
\hline $\mathrm{b}^{\prime} . r_{ \pm}$ & المتوسط & \multirow{2}{*}{ التصميم الساس } \\
\hline 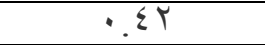 & الانحر اف & \\
\hline b). $0^{\circ \pm}$ & المتوسط & \multirow{2}{*}{ التصميم السابع } \\
\hline$\therefore \mathrm{V}$ & الانحر اف & \\
\hline b).. \pm \pm & المتوسط & \multirow{2}{*}{ التصميم الثامن } \\
\hline $84^{\circ}$. & الانحر اف & \\
\hline b!. $\leqslant \pm$ & المتوسط & \multirow{2}{*}{ التصميم التاسع } \\
\hline .0 & الانحر اف & \\
\hline$a^{r} .9 \pm$ & المتوسط & \multirow{2}{*}{ التصميم العاثر } \\
\hline$\cdot r$ & الانحر اف & \\
\hline
\end{tabular}


مجلة الاقتصاد المنزلي - مجلد هץ ـ العدد الثانى ـ 10 • ب م

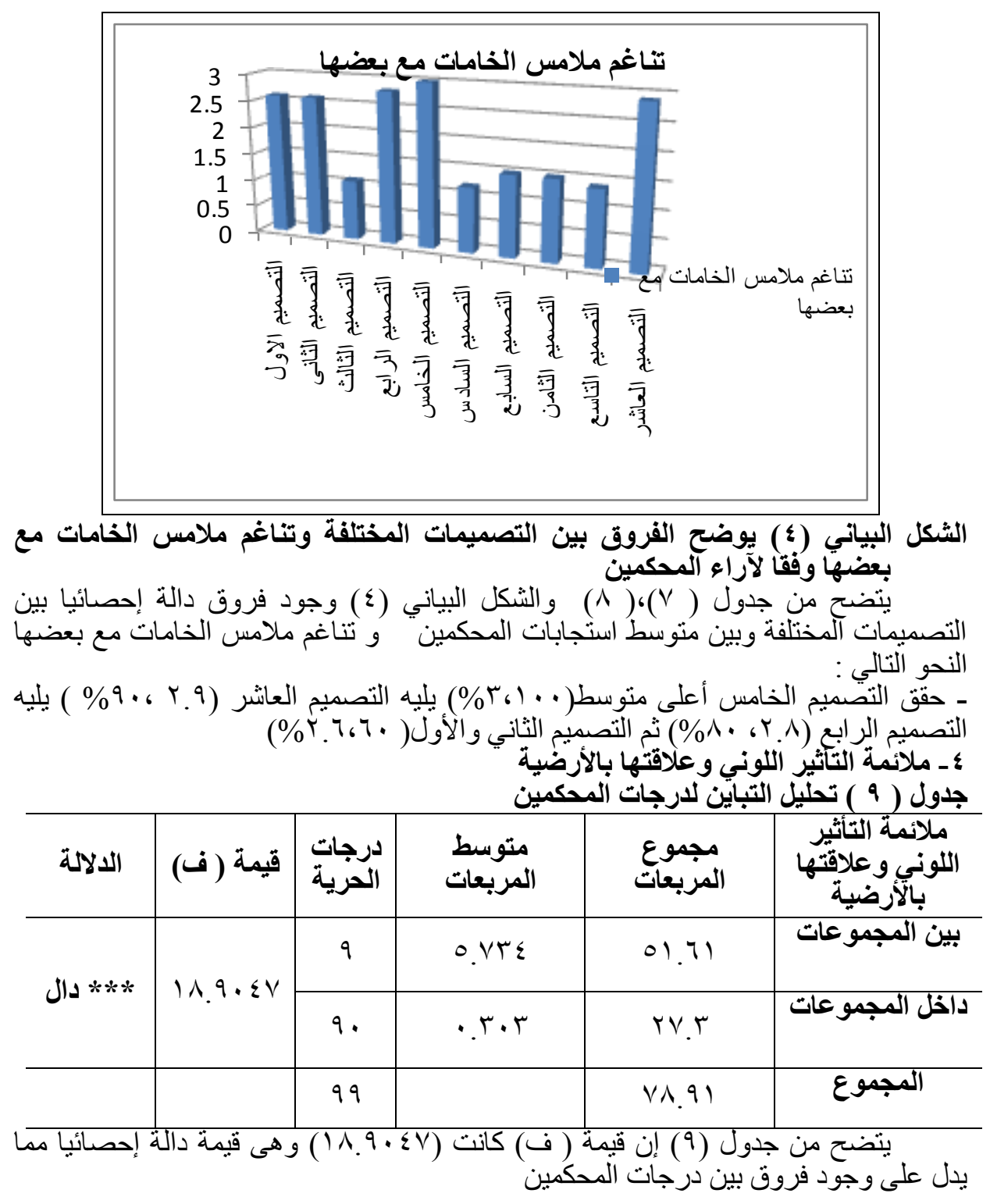


مجلة الاقتصاد المنزلي - مجلد ه بـ العدد الثانى ـ 10 ـ ب م

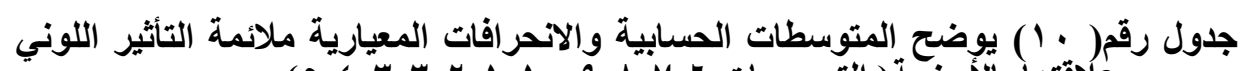

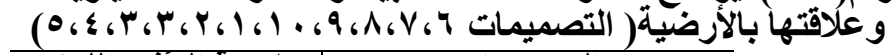

\begin{tabular}{|c|c|c|}
\hline ملائمة التأثير اللوني & \multicolumn{2}{|c|}{ التصميمات } \\
\hline$a^{r} v_{ \pm}$ & المتوسط & \multirow{2}{*}{ التصميم الأول } \\
\hline$\because 0$ & الانحر اف & \\
\hline ar. $^{9} \pm$ & المتوسط & \multirow{2}{*}{ التصميم الثاني } \\
\hline$\cdot . r$ & الانحر اف & \\
\hline b'.1 \pm & المتوسط & \multirow{2}{*}{ التصميم الثالث } \\
\hline$\cdot . r$ & الانحر اف & \\
\hline $\mathrm{a}^{r} . \mathrm{V}_{ \pm}$ & المتوسط & \multirow{2}{*}{ التصميم الر ابع } \\
\hline .0 & الانحر اف & \\
\hline$a^{\Upsilon} . \wedge \pm$ & المتوسط & \multirow{2}{*}{ الخامسمب } \\
\hline $4 \cdot$. & الانحر اف & \\
\hline b). $\varepsilon_{ \pm}$ & المتوسط & \multirow{2}{*}{ التصميم السادس } \\
\hline$\because 0$ & الانحر اف & \\
\hline b).r土 & المتوسط & \multirow{2}{*}{ التصميم السابع } \\
\hline$\because .7 \mathrm{~V}$ & الانحر اف & \\
\hline b). $\leqslant \pm$ & المتوسط & \multirow{2}{*}{ التصميم الثامن } \\
\hline $84^{\circ}$. & الانحر اف & \\
\hline$b^{\prime} . \leqslant \pm$ & المتوسط & \multirow{2}{*}{ التصميم التاسع } \\
\hline$\because \mathrm{V}$ & الانحر اف & \\
\hline ar. $^{\gamma} \pm$ & المتوسط & \multirow{2}{*}{ التصميم العانشر } \\
\hline$\because 0$ & الانحر اف & \\
\hline
\end{tabular}

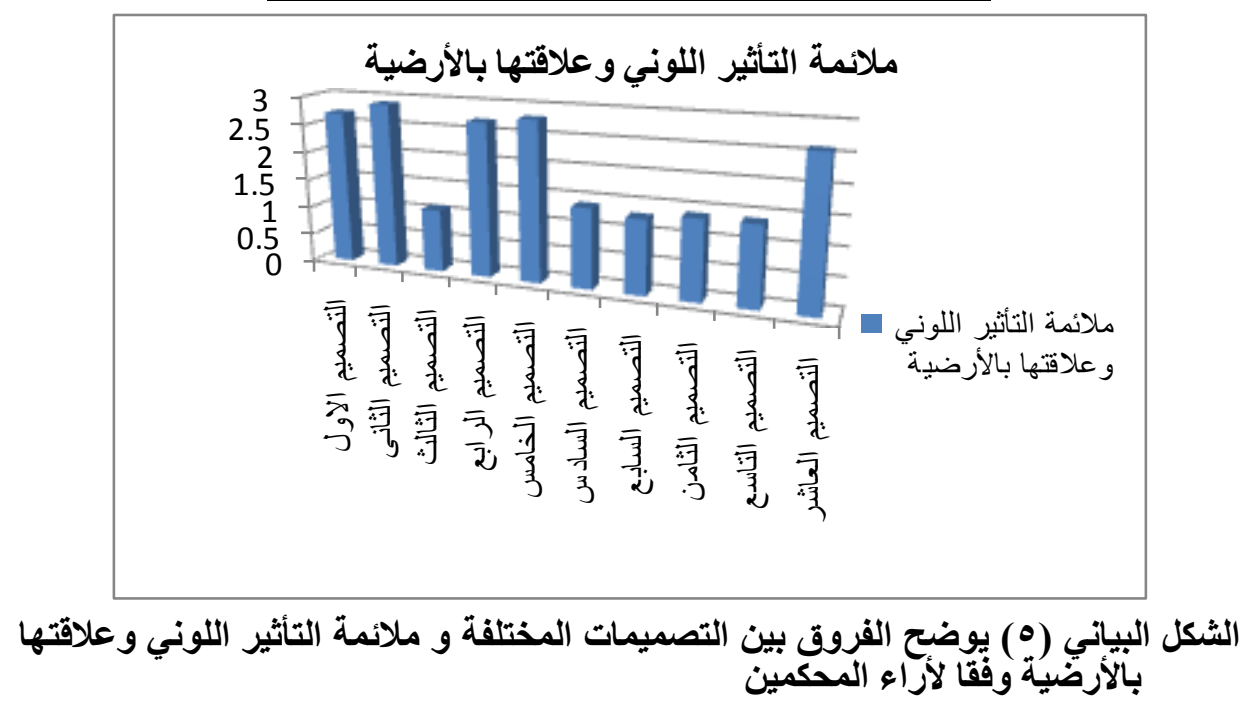




$$
\text { مجلة الاقتصاد المنزلي - مجلد ه بـ العدد الثانى ـ } 10 \text { ب ب م }
$$

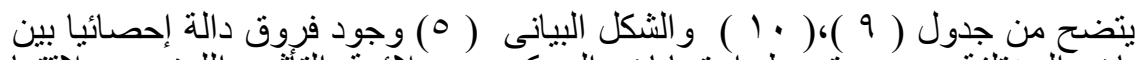

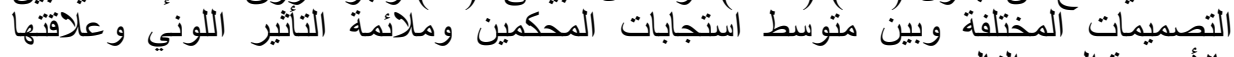

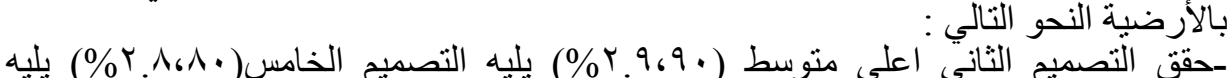

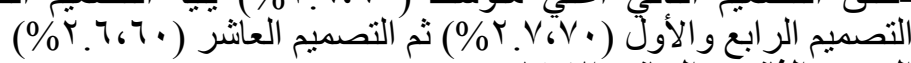
المحور الثاني : الجانب الابتكارى هـ تحقيق الأصالة في التصميم

\begin{tabular}{|c|c|c|c|c|c|}
\hline \multicolumn{6}{|c|}{ جدول (1 1 ) تحليل ألتباين لأرجات المحكمين } \\
\hline 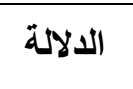 & قيمة (ف) & الحربية & المربعات & المزبعوات & تحقيق الآصميم \\
\hline \multirow{3}{*}{ 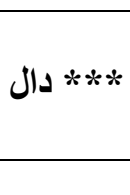 } & \multirow[b]{2}{*}{19.17 .0} & 9 & $\varepsilon .7 \vee 7$ & $\varepsilon r_{.} \cdot q$ & بين آلمجموعات \\
\hline & & 9 . & דצr & $r) . r$ & المجموعات \\
\hline & & 99 & & (4. & المجموع \\
\hline
\end{tabular}

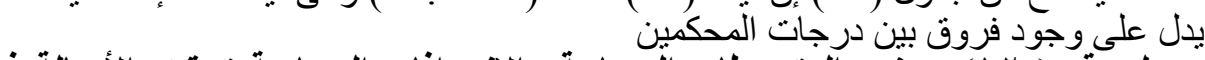

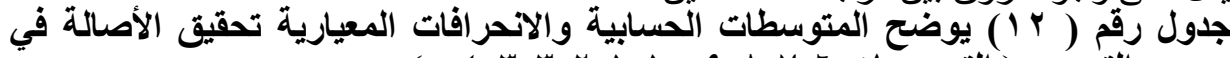

\begin{tabular}{|c|c|c|}
\hline تحقيق الآصالة في & \multicolumn{2}{|c|}{ التصميمات } \\
\hline$a^{r} . V_{ \pm}$ & المتوسط & \multirow{2}{*}{ التصميم الأول } \\
\hline .0 & الانحر اف & \\
\hline$a^{\Gamma \pm}$ & المتوسط & \multirow{2}{*}{ التصميم الثاني } \\
\hline$\cdot$ & الانحر اف & \\
\hline b' $^{\prime} . \Sigma_{ \pm}$ & المتوسط & \multirow{2}{*}{ التصميم الثالث } \\
\hline $5 \cdot$ & الانحر اف & \\
\hline $\mathrm{a}^{\Upsilon} . \wedge \pm$ & المتوسط & \multirow{2}{*}{ التصميم الر ابع } \\
\hline $42 \cdot$. & الانحر اف & \\
\hline$a^{r} v_{ \pm}$ & المتوسط & \multirow{2}{*}{ الخامس } \\
\hline$\therefore 0$ & الانحر اف & \\
\hline b'. $\Sigma_{ \pm}$ & المتوسط & \multirow{2}{*}{ التصميم السادس } \\
\hline .0 & الانحر اف & \\
\hline b'. $7 \pm$ & المتوسط & \multirow{2}{*}{ التصميم السابع } \\
\hline$\because 0$ & الانحر اف & \\
\hline b!. $V_{ \pm}$ & المتوسط & \multirow{2}{*}{ التصميم الثامن } \\
\hline $7 \cdot$. & الانحر اف & \\
\hline b).^土 & المتوسط & \multirow{2}{*}{ التصميم التاسع } \\
\hline$\cdot .74$ & الانحر اف & \\
\hline ar.9 & المتوسط & \multirow{2}{*}{ التصميم العاشر } \\
\hline.$r$ & الانحر اف & \\
\hline
\end{tabular}




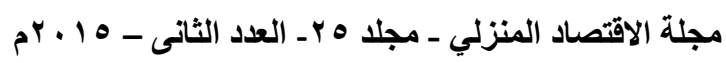

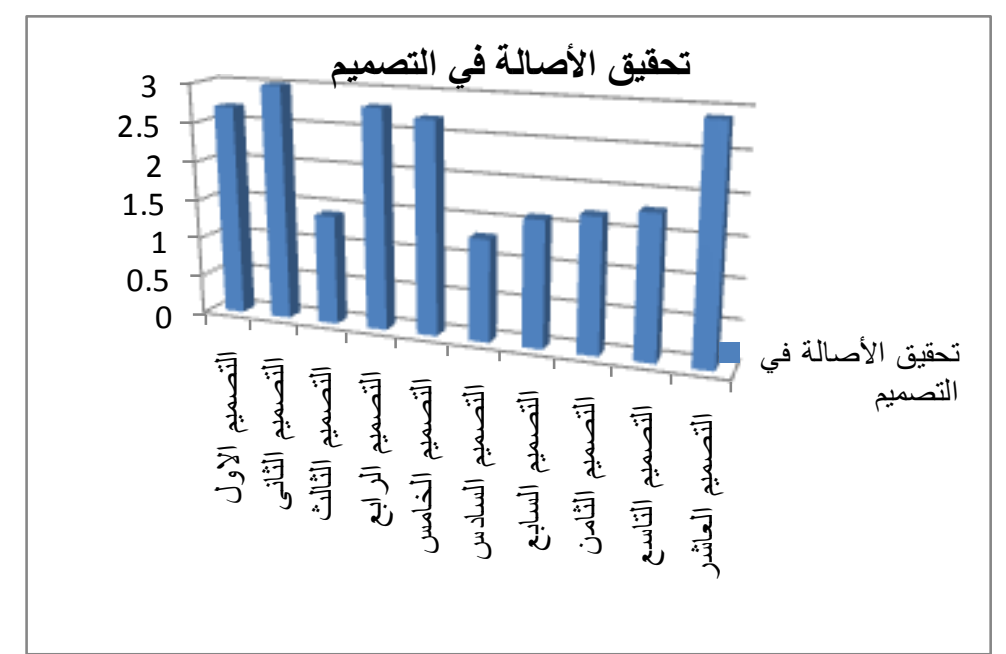

الثكل البياني (ף) يوضح الفروق بين التصميمات المختلفة وتحقيق الأصالة في التصميم وفقا لآراء المحكمين

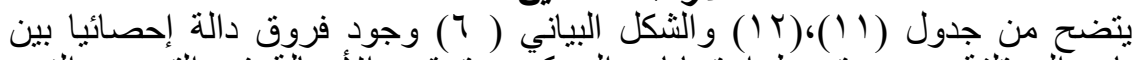

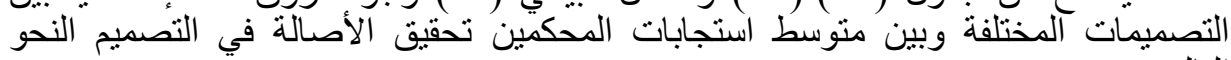

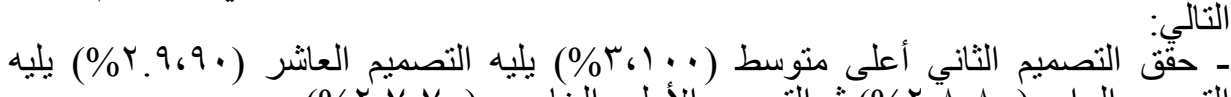

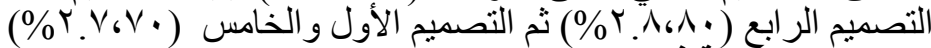
1ا 1 تحقيق الحداثة في التصميم: جذول (با ) تحليل التباين لارجيات المحكمين

\begin{tabular}{|c|c|c|c|c|c|}
\hline الالالة & قيمة (ف) & الحرجية & المربعات & المزبعات & تحقيث التصميم الثة \\
\hline \multirow{3}{*}{ (*** دال } & \multirow{2}{*}{ ro.s. T } & 9 & $7.0 Y_{1}$ & 01.79 & بين المجموعات \\
\hline & & 9 . &. ror & Tr.I & المجموعلات \\
\hline & & 99 & & 1). $\vee 9$ & المجموع \\
\hline
\end{tabular}

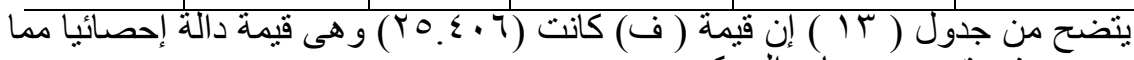
يدل على وجود فروق بين درجات المحكمين 


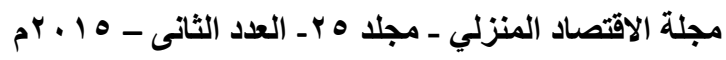

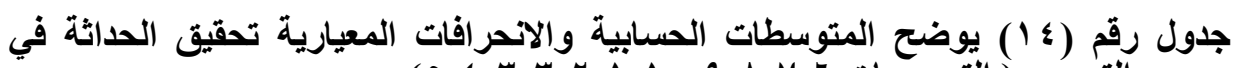

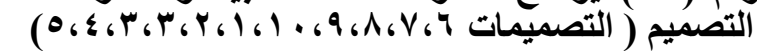

\begin{tabular}{|c|c|c|}
\hline تحقيق الحداثة في & \multicolumn{2}{|c|}{ التصميمات } \\
\hline ar.9. & المتوسط & \multirow{2}{*}{ التصميم الأول } \\
\hline$\cdot . \Gamma$ & الانحر اف & \\
\hline $\operatorname{ar}^{r} .9 \pm$ & المتوسط & \multirow{2}{*}{ التصميم الثاني } \\
\hline$\cdot \pi$ & الانحر اف & \\
\hline b'. Y \pm & المتوسط & \multirow{2}{*}{ التصميم الثالث } \\
\hline $42 \cdot$. & الانحر اف & \\
\hline$a^{r} .9 \pm$ & المتوسط & \multirow{2}{*}{ التصميم الر ابع } \\
\hline$\cdot . T$ & الانحر اف & \\
\hline $\mathrm{a}^{\Upsilon} . \wedge \pm$ & المتوسط & \multirow{2}{*}{ الخامسمب } \\
\hline$\cdot \leqslant Y$ & الانحر اف & \\
\hline b!.1 \pm & المتوسط & \multirow{2}{*}{ التصميم الساد } \\
\hline.$M^{\prime \prime}$ & الانحر اف & \\
\hline b'.rt & المتوسط & \multirow{2}{*}{ التصميم السابع } \\
\hline$\because \varepsilon$ & الانحر اف & \\
\hline b!. $.0 \pm$ & المتوسط & \multirow{2}{*}{ التصميم الثامن } \\
\hline $84 \cdot$. & الانحر اف & \\
\hline b).rt & المتوسط & \multirow{2}{*}{ التصميم التاسع } \\
\hline$\because \mathrm{V}$ & الانحر اف & \\
\hline $\mathrm{a}^{\tilde{\mu} \pm}$ & المتوسط & \multirow{2}{*}{ التصميم العاثر } \\
\hline & الانحر اف & \\
\hline
\end{tabular}

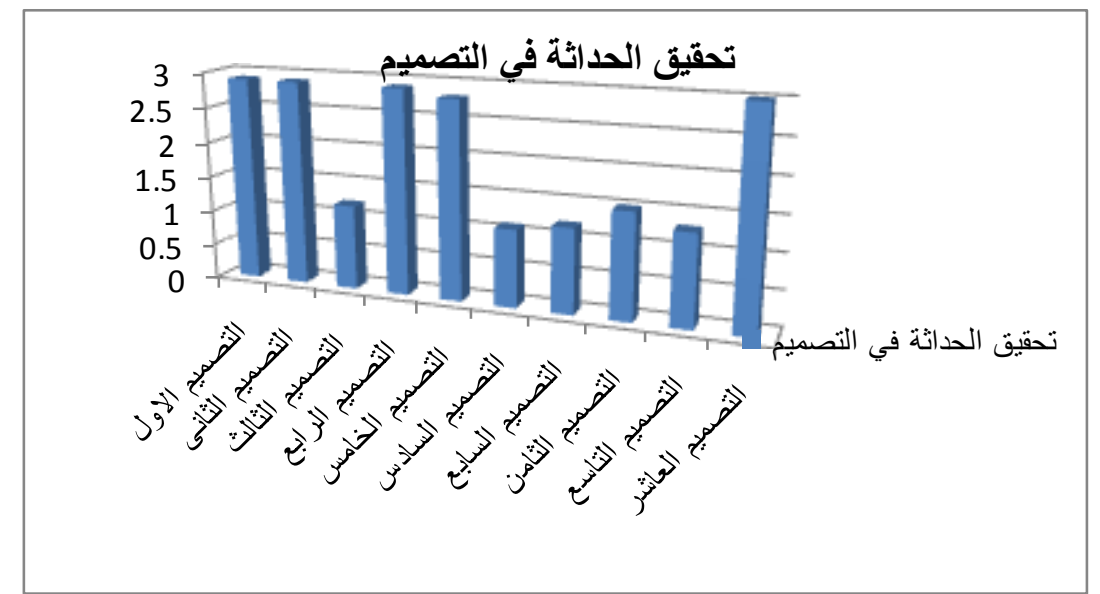

الثكل البياني (V) يوضح الفروق بين التصميمات المختلفة و تحقيق الحداثة في التصميم وفقا لآراء المحكمين المغن 


$$
\text { مجلة الاقتصاد المنزلي - مجلد ه بـ العدد الثانى ـ } 10 \text { ب ب م }
$$

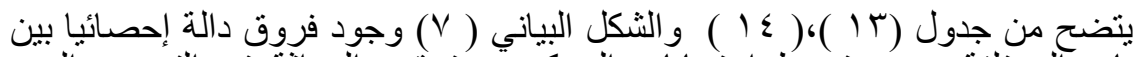
التصميمات المختلفة وبين منوسط استجابات المحكمين وتحقيق الحداثنة في التصميم النحو

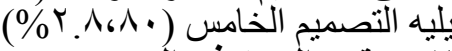

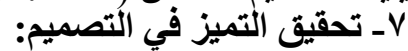
جدول (0 1 ) تحليل التباين لارجات المحكمين

\begin{tabular}{|c|c|c|c|c|c|}
\hline الدلالة & قيمة (ف) & الدرجية & المربعات & المزبعات & تصقيق التميز في \\
\hline \multirow{3}{*}{ (*** دال } & \multirow[b]{2}{*}{ 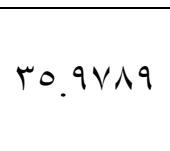 } & 9 & $V .090$ & $7 \Lambda . \% 7$ & بين المجموعات \\
\hline & & 9. & $\cdot r l$ & 19 & المجمو عات \\
\hline & & 99 & & AV.MT & المجموع \\
\hline
\end{tabular}

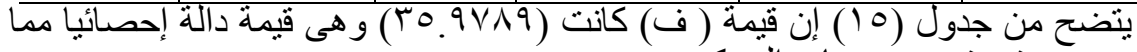

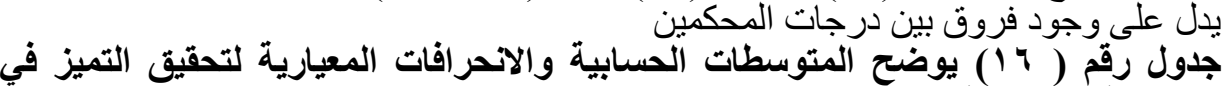

\begin{tabular}{|c|c|c|}
\hline تلتصقيق التميز في & & التصميمات \\
\hline$a^{r} \pm$ & المتوسط & \multirow{2}{*}{ لتصميم الأول } \\
\hline$\cdot$ & الانحر اف & \\
\hline $\mathrm{a}^{\Upsilon} . \wedge_{ \pm}$ & المتوسط & \multirow{2}{*}{ التصميم الثاني } \\
\hline$\cdot . \leqslant Y$ & الانحر اف & \\
\hline$c^{\prime} \cdot Y_{ \pm}$ & المتوسط & \multirow{2}{*}{ التصميم الثالث } \\
\hline $42 \cdot$. & الانحر اف & \\
\hline 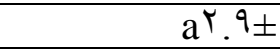 & المتوسط & \multirow{2}{*}{ التصميم الر ابع } \\
\hline$\cdot \mu^{M}$ & الانحر اف & \\
\hline ar. $0^{\circ \pm}$ & المتوسط & \multirow{2}{*}{ الخامسمبم } \\
\hline. $\mathrm{V}$ & الانحر اف & \\
\hline$c^{\prime} \cdot Y \pm$ & المتوسط & \multirow{2}{*}{ التصميم السادس } \\
\hline$\cdot . \leqslant Y$ & الانحر اف & \\
\hline$c^{\prime} .1 \pm$ & المتوسط & \multirow{2}{*}{ التصميم السـابع } \\
\hline$\cdot . T$ & الانحر اف & \\
\hline bc'. ${ }^{7} \pm$ & المتوسط & \multirow{2}{*}{ التصميم الثامن } \\
\hline $7 \cdot$. & الانحر اف & \\
\hline $\mathrm{c}^{\prime} . \Lambda_{ \pm}$ & المتوسط & \multirow{2}{*}{ التصميم التاسع } \\
\hline$\cdot .9$ & الانحر اف & \\
\hline $\mathrm{a}^{\Gamma} \pm$ & المتوسط & \multirow{2}{*}{ التصميم العانشر } \\
\hline - & الانحر اف & \\
\hline
\end{tabular}


مجلة الاقتصاد المنزلي ـ مجلد Oبـ العدد الثانى ـ 10 ب بم

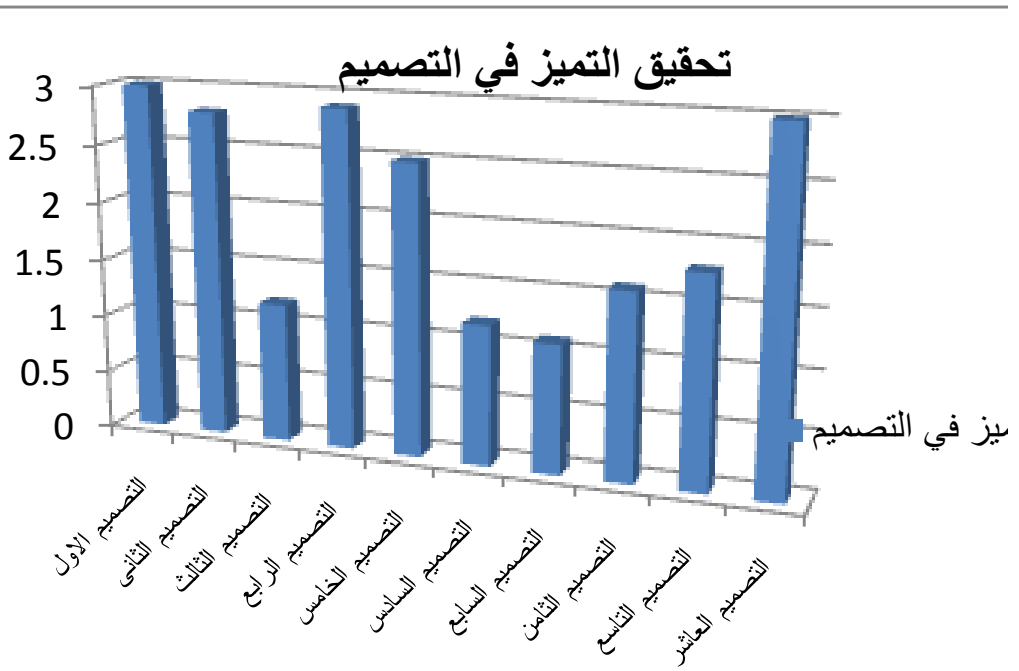

الثكل البياني (^) يوضح الفروق بين التصميمات المختلفة و تحقيق التميز في التصميم وفقا

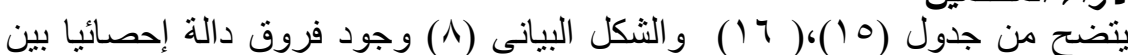

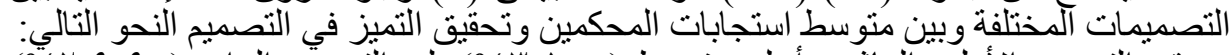

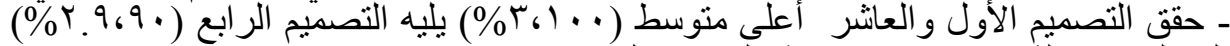

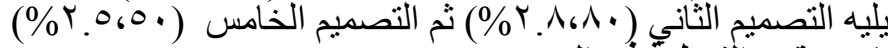

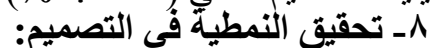

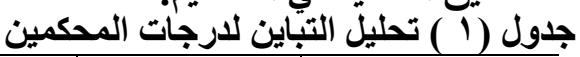

\begin{tabular}{|c|c|c|c|c|c|}
\hline الدلالة & قيمة (ف) & الحرجية & المربعات & مجموع & في التصميم النمطية \\
\hline \multirow{3}{*}{ 柆*** دال } & \multirow{3}{*}{$r \cdot . \wedge 1 \wedge$} & 9 & 7.4711 & OV.YO & بين المجموعات \\
\hline & & 90 &.$r .0$ & rV.O & المجموعات \\
\hline & & 99 & & $\Lambda \varepsilon . \vee 0$ & المجموع \\
\hline
\end{tabular}

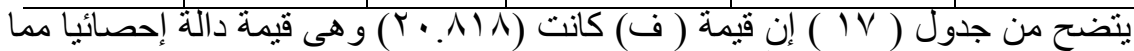
يدل على وجود فروق بين درجات المحكمين 


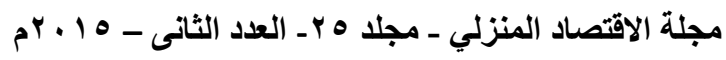

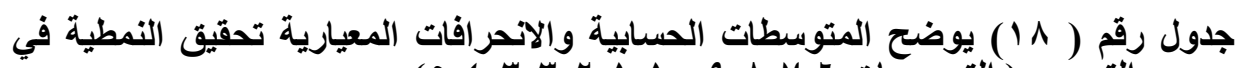

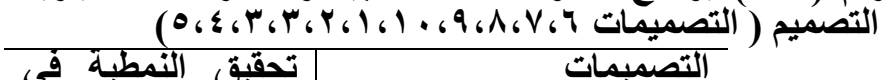

\begin{tabular}{|c|c|c|}
\hline التصقيق النمطية في & & التصميمات \\
\hline$a^{r} .9 \pm$ & المتوسط & \multirow{2}{*}{ التصميم الأول } \\
\hline$\cdot{ }^{\mu}$ & الانحر اف & \\
\hline a $9.9 \pm$ & المتوسط & \multirow{2}{*}{ التصميم الثاني } \\
\hline 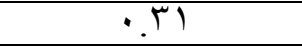 & الانحر اف & \\
\hline b).r土 & المتوسط & \multirow{2}{*}{ التصميم الثالث } \\
\hline $5 \cdot$. & الانحر اف & \\
\hline $\mathrm{a}^{\Upsilon} . \wedge \pm$ & المتوسط & \multirow{2}{*}{ التصميم الر ابع } \\
\hline. .74 & الانحر اف & \\
\hline ar. $^{7} \pm$ & المتوسط & \multirow{2}{*}{ الخامس } \\
\hline$\because \mathrm{V}$ & الانحر اف & \\
\hline bl.r土 $^{\prime}$ & المتوسط & \multirow{2}{*}{ التصميم السادس } \\
\hline$\cdot . \leqslant T$ & الانحر اف & \\
\hline$b^{\prime} . r \pm$ & المتوسط & \multirow{2}{*}{ التصميم السابع } \\
\hline 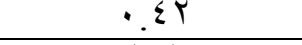 & الانحر اف & \\
\hline b). $\leqslant \pm$ & المتوسط & \multirow{2}{*}{ التصميم الثامن } \\
\hline $84 \cdot$. & الانحر اف & \\
\hline b). $\leqslant \pm$ & المنو سط & \multirow{2}{*}{ التصميم التاسع } \\
\hline$\because \mathrm{V}$ & الانحر اف & \\
\hline $\mathrm{a}^{\top} . \wedge \pm$ & المتو سط & \multirow{2}{*}{ التصميم العاشر } \\
\hline 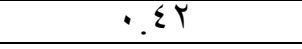 & الانحر اف & \\
\hline
\end{tabular}

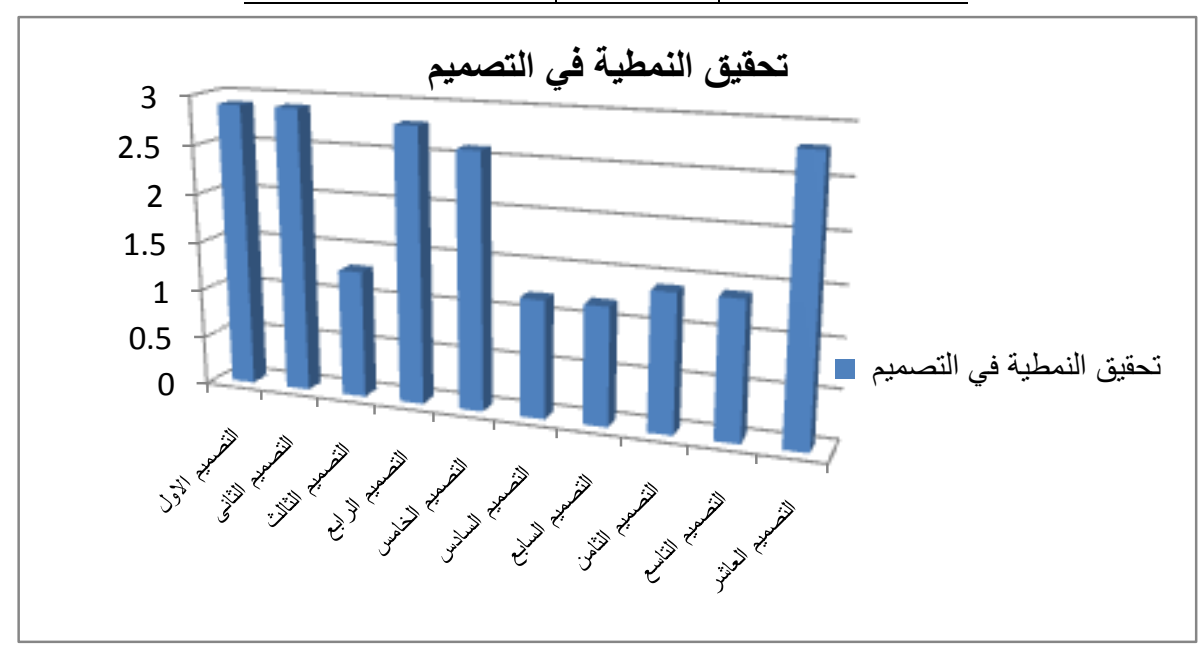

الثكل البياني (9) يوضح الفروق بين التصميمات المختلفة و تحقيق النمطية في التصميم وفقا لأراء المحكمين 


\section{مجلة الاقتصاد المنزلي ـ مجلد ه بـ العدد الثانى ـ 10 ب ب م}

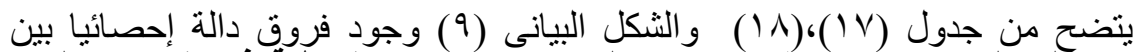
التصميمات المختلفة وبين منوسط استجابات المحكمين وتحقيق النمطية في التصميم النحو بين

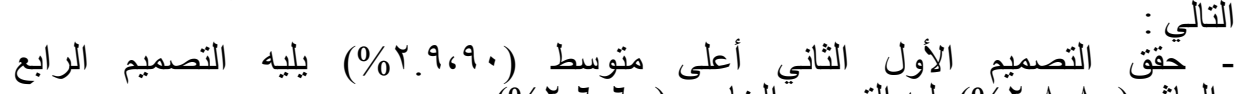

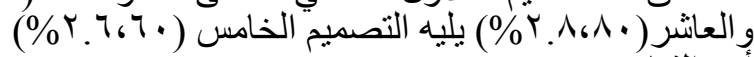
أهم النتائج

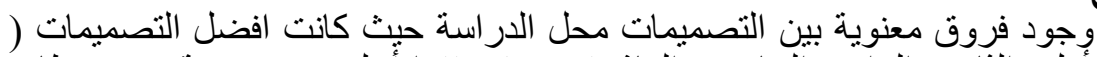

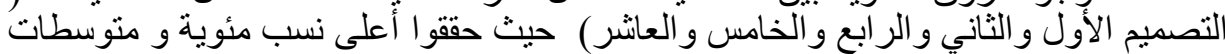
في بنود الاستبيان

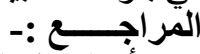

ا ـ أهداف كمال الدين "الملامس كقيمة تشكيلية جمالية في التصميم الطباعي "المؤتمر العلمي

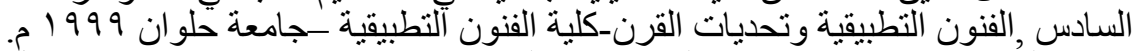

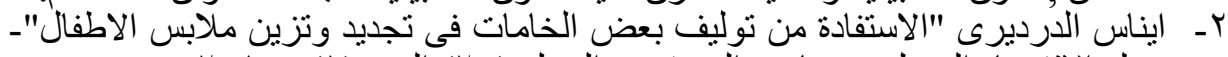

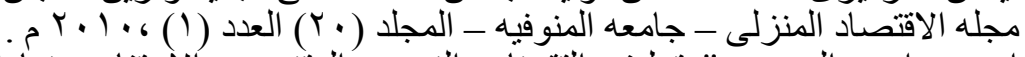

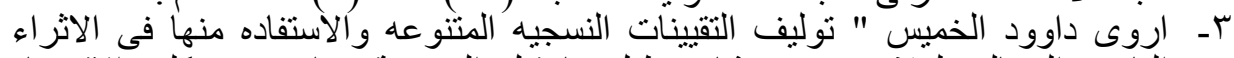

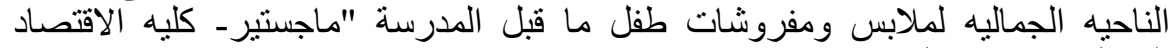

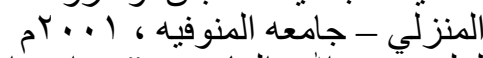

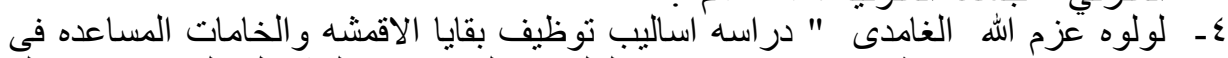

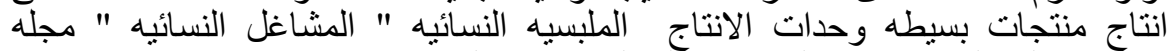

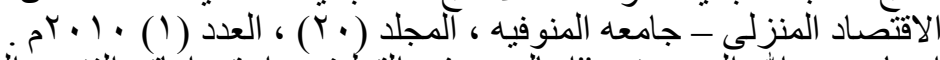

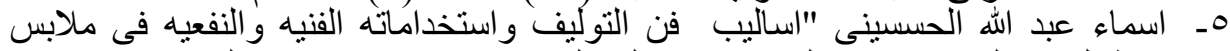

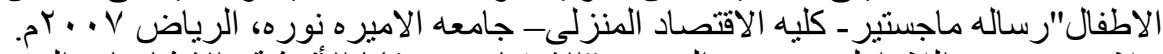

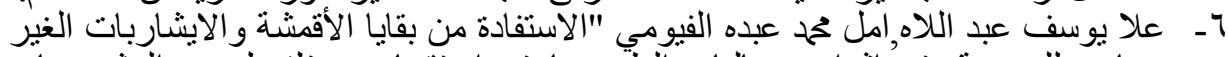

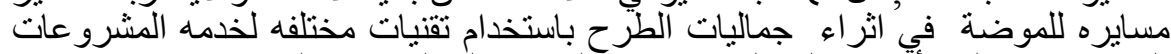

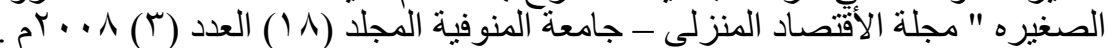

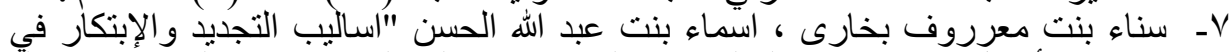
ملابس الأطفال باستخدام فن التوليف" مجلة الاقتصاد المنزلي - جامعة المنوفية - مجلد

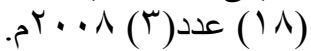

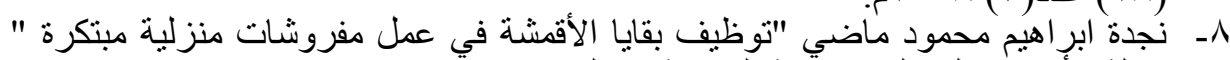

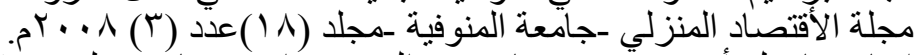

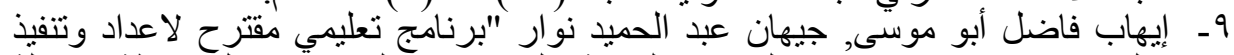

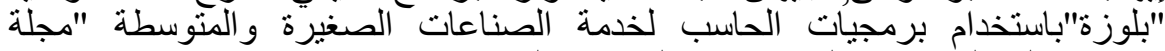

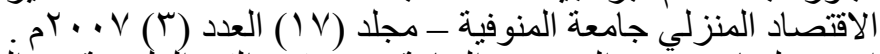

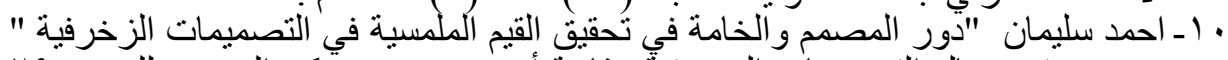

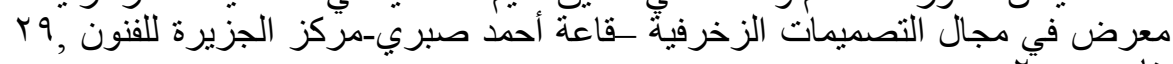

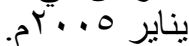
1 ا ـ هند محمد إبر اهيم "تتمية التفكير الابتكاري للمر أة في توليف خامات البياتئة المنزلية المستهولكة

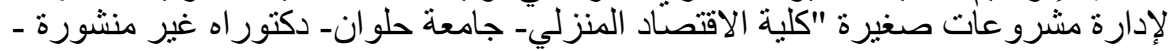

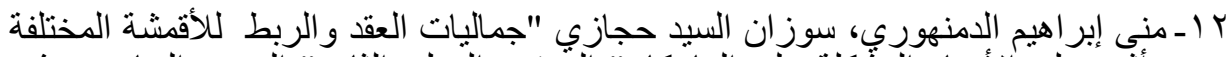

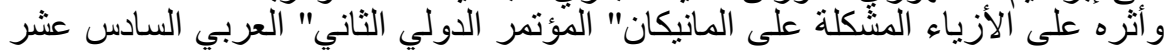




\section{مجلة الاقتصاد المنزلي - مجلد ه بـ العدد الثانى ـ 1 ـ بrم}

للاقتصاد المنزلي" جامعة المنوفية "الاقتصاد المنزلي في خدمة الصناعة"•.

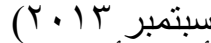

rا أسماء أحمد عبد الرحمن الثريف "توليف خامات البيئة لإنتاج بعض الأعمال الفنية من فنون الزخارف المكسيكية " كلية الاقتصاد المنزلي- جامعة المنوفية لإنية ـ ماجستير غير الإنية

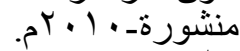

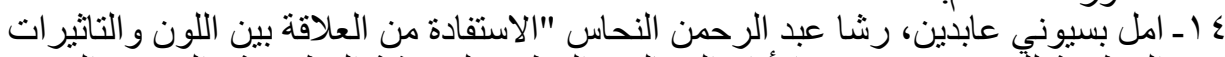

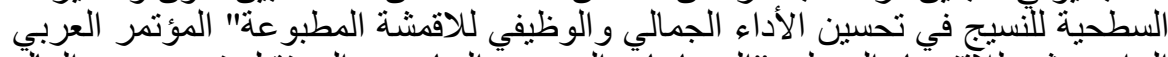

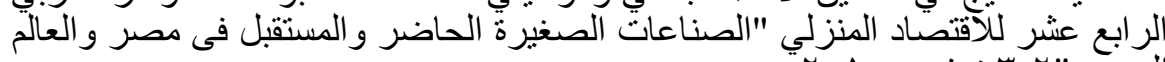

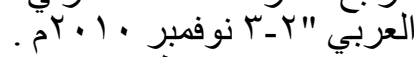

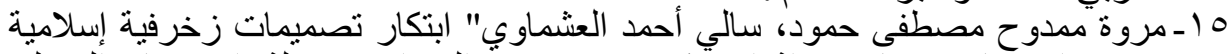

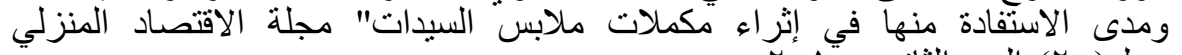

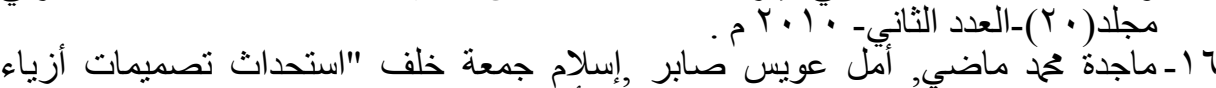

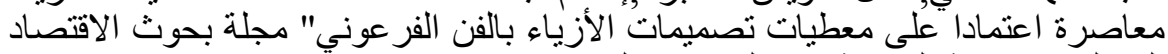

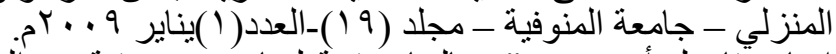

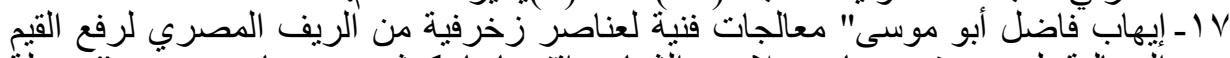

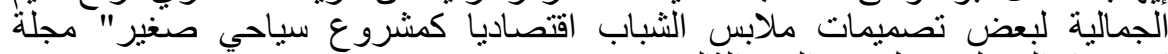

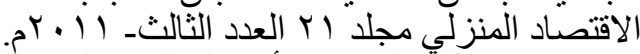

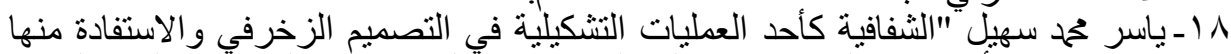

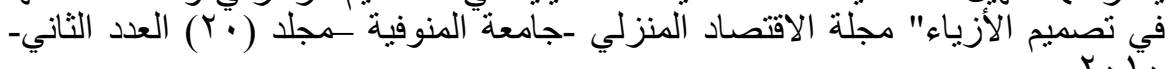
.

9 اـزكية سيد رمضان: "تزاوج خامات الثكل المجسم في النحت الحديث و وأثره على القيم

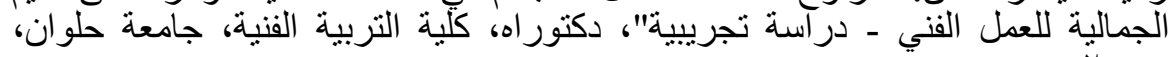
r... • • - رحاب عدل الفيشاوي" دراسة لبعض الاساليب الزخرفية لأثراء القيم الجمالية لملابس

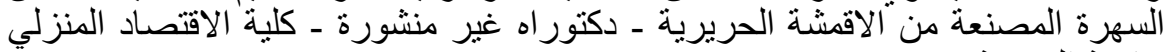

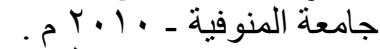

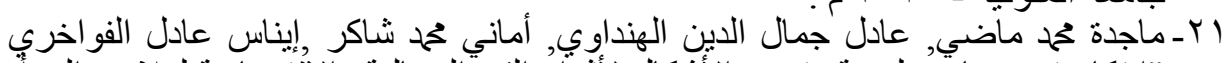

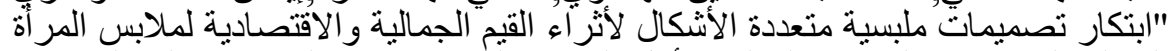

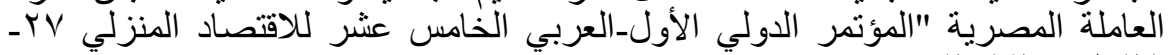

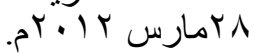

